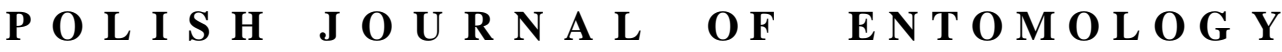

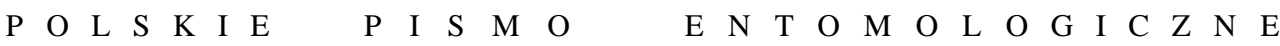

VOL. 86: $303-345$

Lublin

31 December 2017

DOI: $10.1515 /$ pjen-2017-0018

\section{Systematics and faunistics of Neotropical Eucosmini, 3: Epinotia-group of genera (Lepidoptera: Tortricidae)}

\author{
JÓZEF RAZOWSKI $^{1 *}$, VITOR O. BECKER ${ }^{2}$ \\ ${ }^{1}$ Institute of Systematics and Evolution of Animals, Polish Academy of Sciences, Kraków, \\ 31-016 Sławkowska 17, Poland \\ ${ }^{2}$ Reserve Serra Bonita, P.O. Box 01, 45880 Camacan BA, Brazil
}

\begin{abstract}
Four genera - Domaldona gen. n., Iatitaia gen. n., Miojuqa gen. n., and Latortona gen. n. - and 28 species are described as new: Quebradnotia venezolana sp. n., Q. paulista sp. n., Laculataria brunnescens sp. n., L. cactsocia sp. n., L. elliptica sp. n., L. atrovirens sp. n., L. cajasana sp. n., Crocidosema monias sp. n., C. obliquata sp. n., C. platea sp. n., C. mangaritibae sp. n., Domaldona latiptera sp. n., Iatitaia itatiaiae sp. n., I. pithana sp. n., I. intercalata sp. n., Miojuqa visibilis sp. n., $M$. albivertex sp. n., M. splendida sp. n., M. defecta sp. n., M. viridicans sp. n., Latortona tortolana sp. n., L. rhamna sp. n., L. viridirufa sp. n., L. tornota sp. n., L. vulga sp. n., L. mimosa sp. n., L. cosmelia sp. n., L. diplocosmea sp. n. Two species are redescribed - Quebradnotia nolckeniana (ZELLER, 1877), Latortona nigroapicata (RAZOWSKI \& WOJTUSIAK, 2006) - and two species are transferred to new genera: Crocidosema dolicha (RAZOWSKI \& WOJTUSIAK) comb. n. from Pseudexentera; Miojuqa beryllina from Eucosma. Ten new combinations: Crocidosema albocephalaeis RAZOWSKI \& WOJTUSIAK, 2010, comb. n.; $C$. brunneomacula RAZOWSKI \& WOJTUSIAK, 2009, comb. n.; $C$. chloana RAZOWSKI \& WOJTUSIAK, 2006b, comb. n.; C. illepidosa RAZOWSKI \& WOJTUSIAK, 2006b, comb. n.; C. lineana RAZOWSKI \& WOJTUSIAK, 2008a, comb. n.; C. longistria RAZOWSKI \& WOJTUSIAK, 2008c, comb. n.; $C$. marcapatae RAZOWSKI \& WOJTUSIAK, 2010, comb. n.; $C$. microscyphos RAZOWSKI \& LANDRY, 2008, comb. n.; C. panda RAZOWSKI \& WOJTUSIAK, 2008b, comb. n.; C. rotundata RAZOWSKI \& WOJTUSIAK, 2009, comb. n. is transferred from Epinotia to Crocidosema. One new synonymy is proposed: Epinotia tubuligera RAZOWSKI \& WOJTUSIAK, 2008 is conspecific with Laculataria nigroapicata.
\end{abstract}

KEY WORDS: Lepidoptera, Tortricidae, Eucosmini, Epinotia-group, Neotropics.

* Corresponding author: Razowski@isez.pan.krakow.pl 


\section{INTRODUCTION}

The "Epinotia-group" was proposed by HORAK (2006) who stated that it "is merely a convenient informal genus-group, corresponding to RAZOWSKI's (1987) tentative Epinotia/Zeiraphera/Crocidosema lineage." She included in it only Epinotia HÜBNER, [1825] 1816 and Crocidosema ZELLER, 1847 and diagnosed and redescribed the latter. HORAK (2006) also suggested that the group is not monophyletic and that it does not deserve a formal rank. We agree with that conclusion and it is further emphasized by the fact that several additional genera related to Epinotia have been discovered. Thus, we review and comment on all known related genera arranged in alphabetical order. The senior author plans to re-examine the systematics and phylogeny of the group based on molecular data (COI), but the main difficulty is in the examination of poorly known species, primarily those from the Neotropics. The problem also involves the interpretation of the described genera and the correct systematic position of many species within the particular genera. These problems remain unsolved.

\section{Review of the genera}

The references to species and genera are in the catalogue by BROWN (2005) and the publications mentioned below.

\section{Argepinotia RAzowSKI \& Pelz, 2007}

Argepinotia was diagnosed as related to Epinotia from which it is distinguished by a broad terminal part of the tegumen, long lateroterminal socii, and a large densely hairy lobe of the posterior edge of the basal cavity of the valva.

Argepinotia is a monotypic genus known only from South America (Argentina).

\section{Catastega Clemens, 1861}

Catastega was traditionally synonymized with Epinotia, but it was resurrected by BROWN (1986) on the basis of the shapes of the anellus and sterigma. However, the enlarged anellus surrounding the phallobase occurs in several genera and the differences of the sterigma are probably inconsistent. BROWN (2005) included nine Nearctic species.

\section{Chimoptesis PoWELL, 1964}

POWELL (1964) described the genus for four Nearctic species, and these were listed by BROWN (2005). RAZOWSKI \& BECKER (2015) commented on the genus and described 20 new species, extending the geographic distribution of the genus to the Neotropics. 
In facies, Chimoptesis species are similar to Epinotia and Crocidosema, but they can be distinguished from them chiefly by the broad uncus, the lateral position of the socii, and the posterior emargination of the female subgenital sternite.

\section{Crocidosema ZELLER, 1847}

BROWN (2005) and HORAK (2006) recorded two synonyms of Crocidosema. The genus was redescribed and diagnosed by RAZOWSKI $(1989,2003)$ and HORAK $(2006)$; in those papers the morphology of the female scent organs and the lobes of the female subgenital sternite are mentioned as the supposed autapomorphies for this genus.

Crocidosema is distributed in all the regions, and C. plebeiana is cosmopolitan. BROWN (2005) listed twenty-four species but some of them require re-examination. RAZOWSKI \& BECKER (2014) commented on the genus and described 18 new Neotropical species. The morphological characters occasionally differ from those mentioned by RAZOWSKI (1989) and HORAK (2006) and of the type species. A reassessment of several characters is required. The characters given by RAZOWSKI $(1989,2003)$ and HORAK (2006) are consistent for the $C$. plebeiana and $C$. lantana groups, but in many species they are variable or absent, such as the structure of the female subgenital sternite. In many species of Epinotia there are various sclerotized folds (see RAZOWSKI (2003) for European species), but the presence of the scent scales needs confirmation.

\section{Epinotia HÜBNER [1825] 1816}

RAZOWSKI $(1987,1989)$ redescribed Epinotia and synonymized the subgenera earlier used by several authors (e.g. SWATSCHEK, 1958; HANNEMANN, 1961). He also listed its supposed autapomorphies, chiefly the structure of the henion. RAZOWSKI (2003) listed 25 synonyms of Epinotia, including Catastega.

The type-species of some former subgenera need re-consideration and would benefit from molecular analyses. We agree with the opinion by HORAK (2006) that the problem of the Epinotia-group of genera, especially Epinotia, should be left open until a cladistic analysis is completed.

Epinotia is known from all the zoogeographic regions.

\section{Laculataria RAZOWSKI \& WOJTUSIAK, 2006}

Laculataria was described for three Neotropical species in the Epinotia-group. It differs from Epinotia in having a dentate socius with outer setae (in the type-species, L. asymmetra RAZOWSKI \& WOJTUSIAK, 2006). Other species described in same paper have different socii but have similar valvae with a non-angulate sacculus and a long uncus and may belong to another genus. In the species of Laculataria described in this paper the socii are setose or have 
pockets filled with dense hairs. The females are characterized by large posterior lobes of the subgenital sternite and sclerotized folds of the lobes similar to those of Crocidosema and Epinotia.

\section{Quebradnotia RAZOWSKI \& WOJTUSIAK, 2006}

Quebradnotia originally consisted of four Neotropical species. It is similar to Epinotia but distinguished by the apomorphic structure of the socii which consist of two parts, a submembranous inner lobe and a rigid process connected with the henion. The female (described in this paper) has a membranous sterigma and a simple subgenital sternite (without a scent organ).

\section{Zerpanotia RAZOWSKI \& WOJTUSIAK, 2006}

This is a monotypic Neotropical genus similar to Epinotia and Taiwanancylis RAzOwSKI, 2000. Zerpanotia is characterized by the strong spines on the distal end parts of the uncus and socii; the shape of the valva; a minute, well sclerotized sterigma with a median ostium bursae; and the sclerite of the antrum fused with the cingulum.

\section{MATERIAL}

The specimens examined in this paper were collected by the second author. The types of the newly described species are temporarily housed in the Vitor BECKER collection (VBC) and will eventually be deposited in one of the Brazilian museums. A few specimens have been kindly donated to the Institute of Systematics and Evolution of Animals, Polish Academy of Sciences, Kraków (ISEZ). The numbers cited on the labels of the specimens are the entry numbers in the register book of the second author.

Abbreviations used: MZUJ - Zoological Museum of the Jagiellonian University, NHML - Natural History Museum London (formerly the British Museum (Natural History), WZ - Witold ZAJDA.

\section{Acknowledgements}

We thank the anonymous reviewer for the helpful remarks and linguistic corrections. 
RAZOWSKI J. and BECKER V.O.: Systematics and Faunistics of Neotropical Eucosmini 307

RESULTS

Quebradnotia nolckeniana (ZELLER, 1877)

(Fig. 28)

\section{Remarks}

Q. nolckeniana was described from a pair of moths collected in Colombia. We examined a female from Medina (taken at an altitude of 1650 feet) that does not differ from the male lectotype except for the head colour which in the former is blackish (according to the original description the head is whitish in the female lectoparatype). The type material is housed in the NHML.

\section{Description}

Female genitalia (Fig. 28). Ovipositor moderately long; apophyses long; eighth tergite short; sterigma rudimentary, ostium area membranous; antrum sclerite long, indistinct proximally; cingulum very long, broadening proximally with submedian origin of ductus seminalis; membranous part of ductus between the two sclerites proportionally short; signa large. Subgenital sternite elongate, tapering posteriorly, without scent organ, with large inner posterior membranous emargination.

\section{Quebradnotia venezolana sp. n.}

\section{Diagnosis}

Q. venezolana differs from the Colombian $Q$. nolckeniana chiefly in the forewing having white dorsal areas and lacking a pale brownish subcostal marking; and having an ill-defined sterigma and small signa, which in $Q$. nolckeniana are very large.

\section{Description}

Wing span $17 \mathrm{~mm}$. Head and thorax greenish white, tegula blackish. Ground colour of forewing white, suffusions greenish. Markings confluent, brown-black. Hindwing white tinged brown in apical area.

\section{Material}

Holotype male: Cordillera de Merida, Monte Zarpa, 3250 m, Coll. MZUJ. 

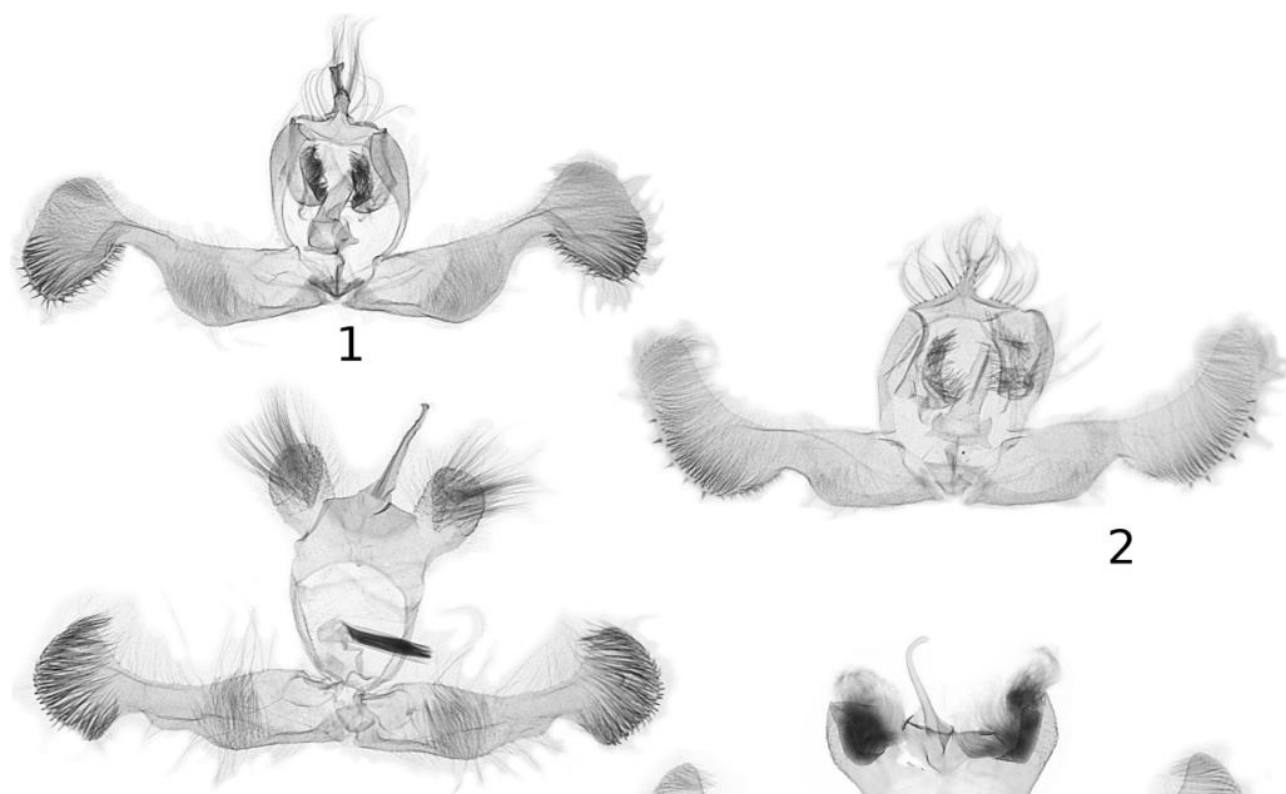

3

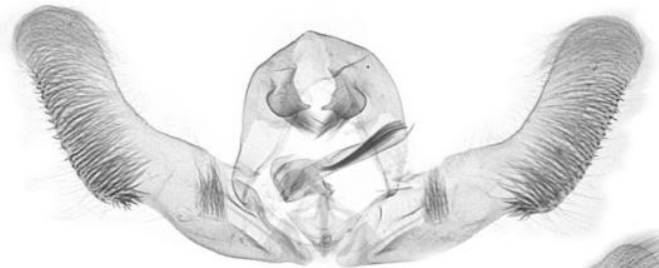

4

5

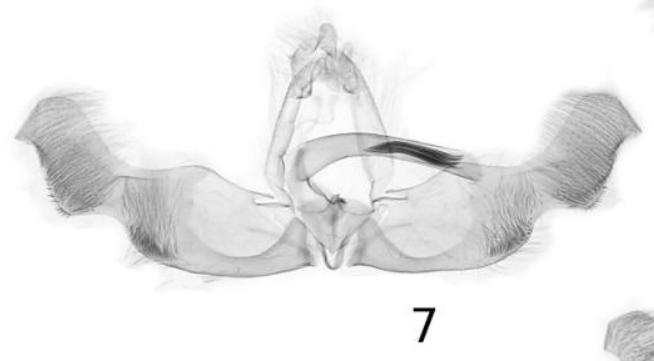

6

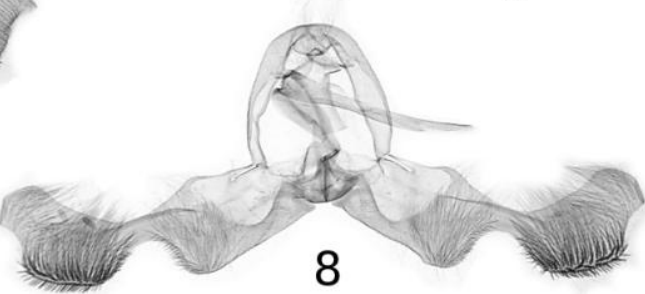

Figs 1-8. Male genitalia: 1 - Laculataria brunnescens sp. n., holotype, 2 - L. cactsocia sp. n., holotype, 3 - L. elliptica sp. n., holotype, 4 - L. cajasana sp. n., holotype, 5 - Crocidosema monias sp. n., holotype, 6 - C. obliquata sp. n., holotype, 7 - Crocidosema sp., GS 1035 WZ, $8-$ C. platea sp. n., holotype. 


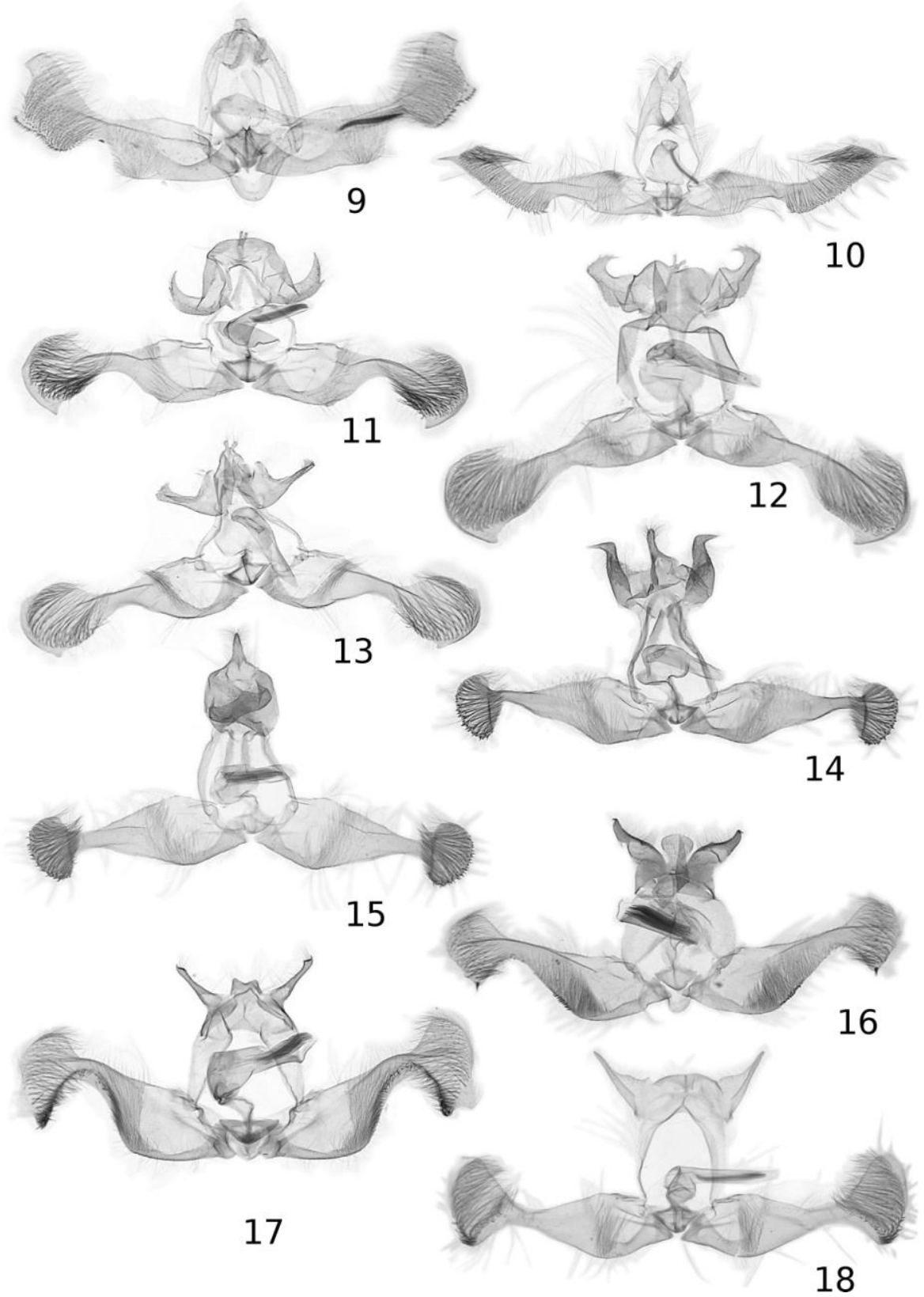

Figs 9-18. Male genitalia: 9 - Crocidosema mangaritibae sp. n., holotype, 10 - Domaldona latiptera sp. n., holotype, 11 - Iatitaia itatiaiae sp. n., holotype, 12 - I. pithana sp. n., holotype, 13 - I. intercalata sp. n., holotype, 14 - Miojuqa visibilis sp. n., holotype, 15 - M. albivertex sp. n., holotype, $16-$ M. albovirens sp. n., holotype, 17 - Miojuqa splendida sp. n., holotype, $18-$ M. defecta sp. n., holotype. 


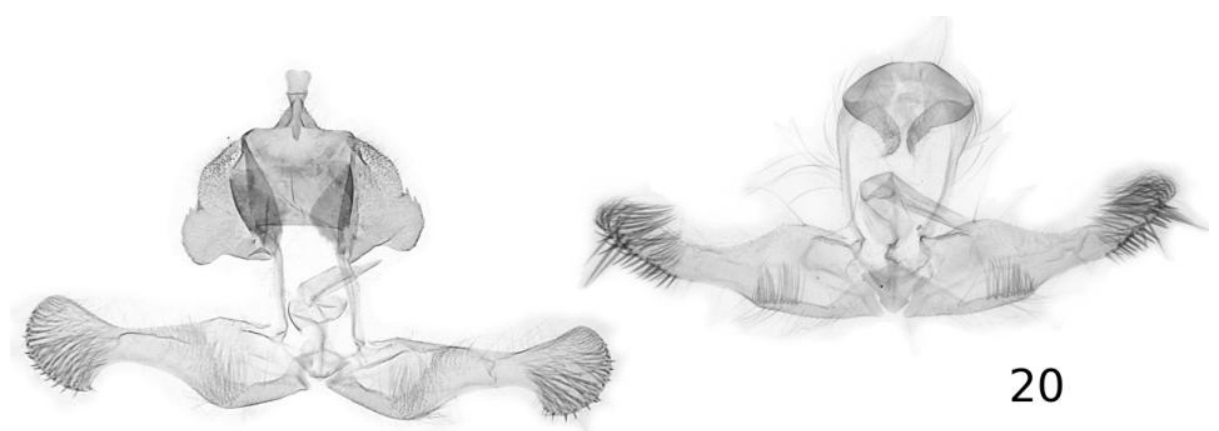

19
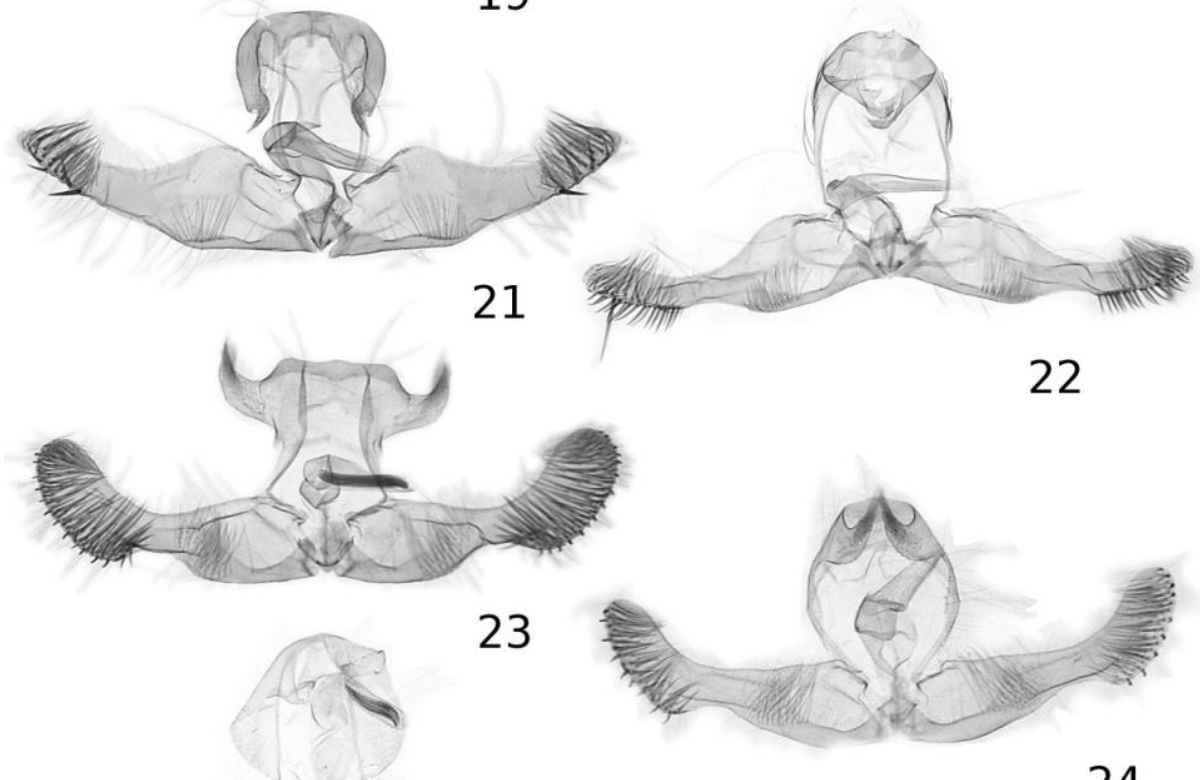

24

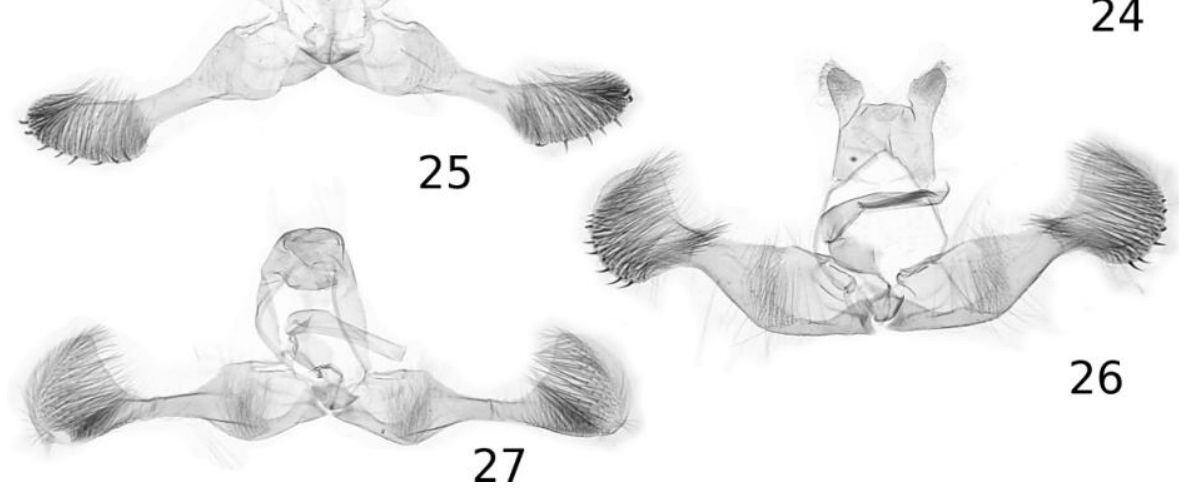

Figs 19-27. Male genitalia: 19 - Miojuqa viridicans sp. n., holotype, 20 - Latortona tortolana sp. n., holotype, 21 - L. rhamna sp. n., holotype, $22-L$. viridirufa sp. n., holotype, $23-L$. tornota sp. n., holotype, $24-L$. vulga sp. n., holotype, $25-L$. mimosa sp. n., holotype, $26-L$. cosmelia sp. n., holotype, $27-$ L. diplocosmea sp. n., holotype. 

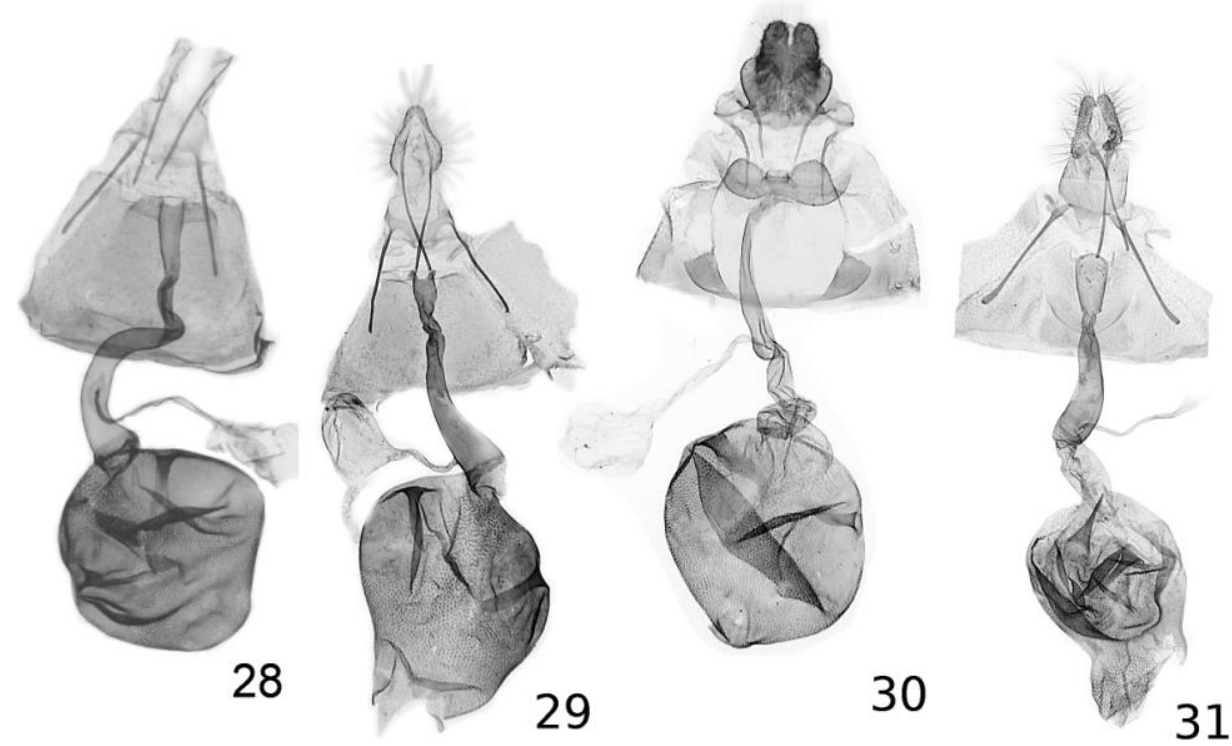

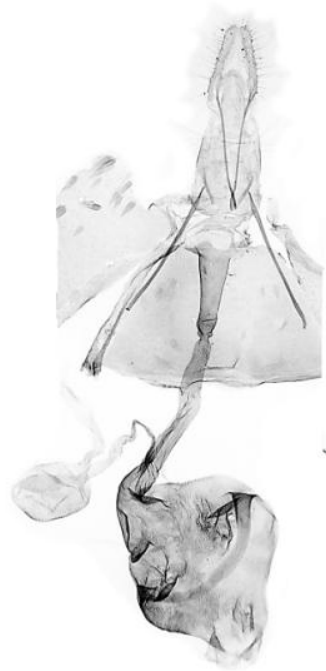

32

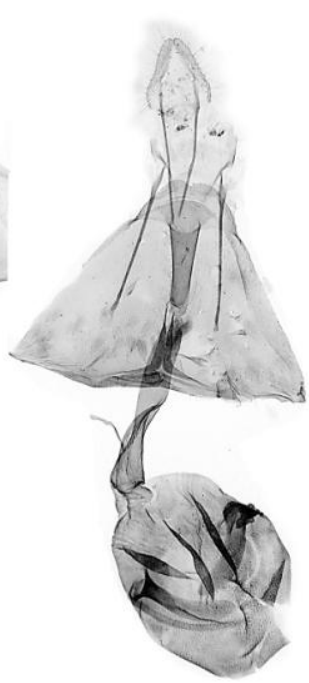

33

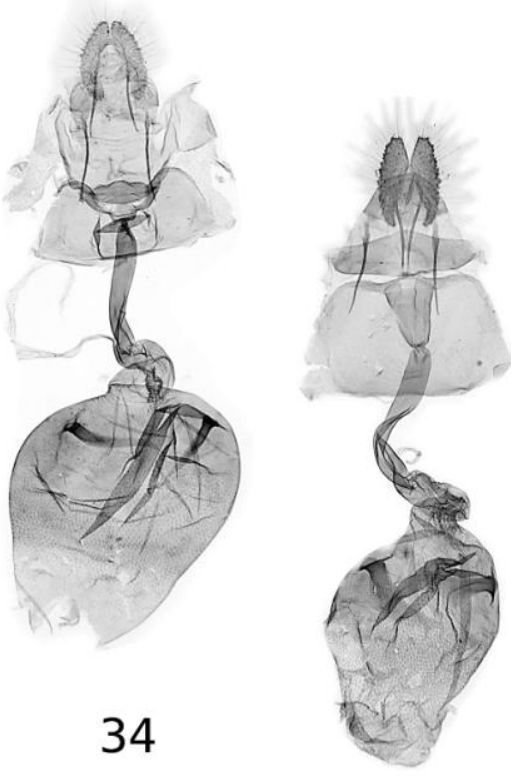

35

Figs 28-35. Female genitalia: 28 - Quebradnotia nolckeniana, Medina, Colombia, $29-Q$. paulista sp. n., holotype, 30 - Laculataria atrovirens sp. n., holotype, 31 - Crocidosema monias sp. n., paratype, 32 - Crocidosema sp., GS 1034 WZ, 33 - C. platea sp. n., paratype, 34 - Iatitaia itatiaiae sp. n., paratype, 35 - I. pithana sp. n., paratype. 

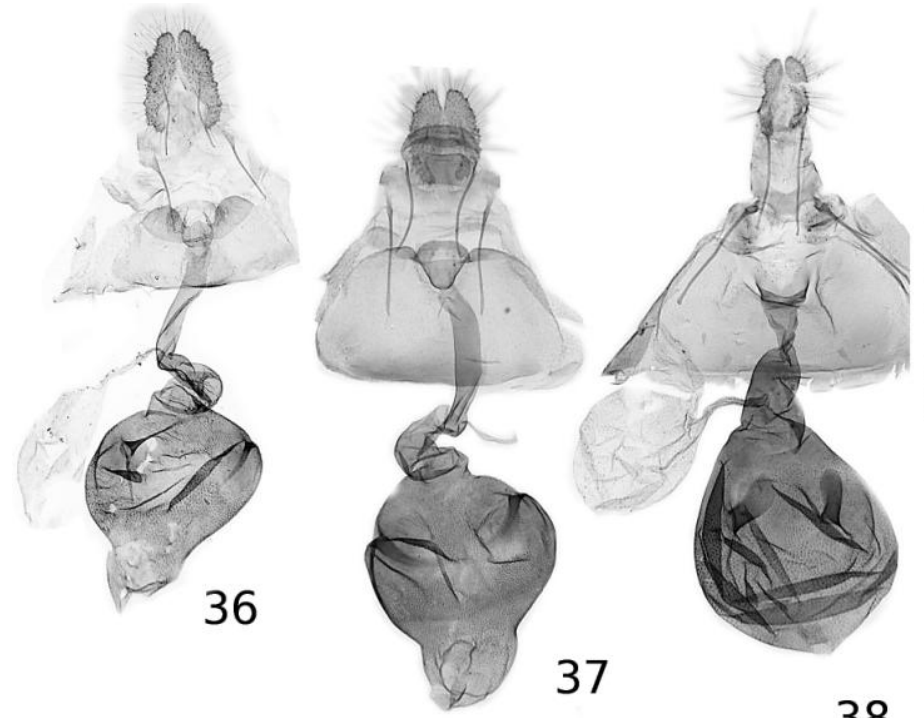

38

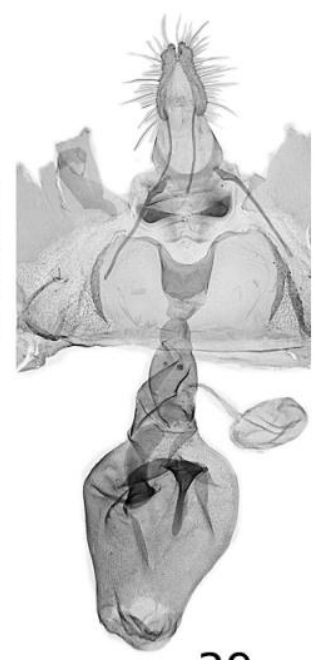

39

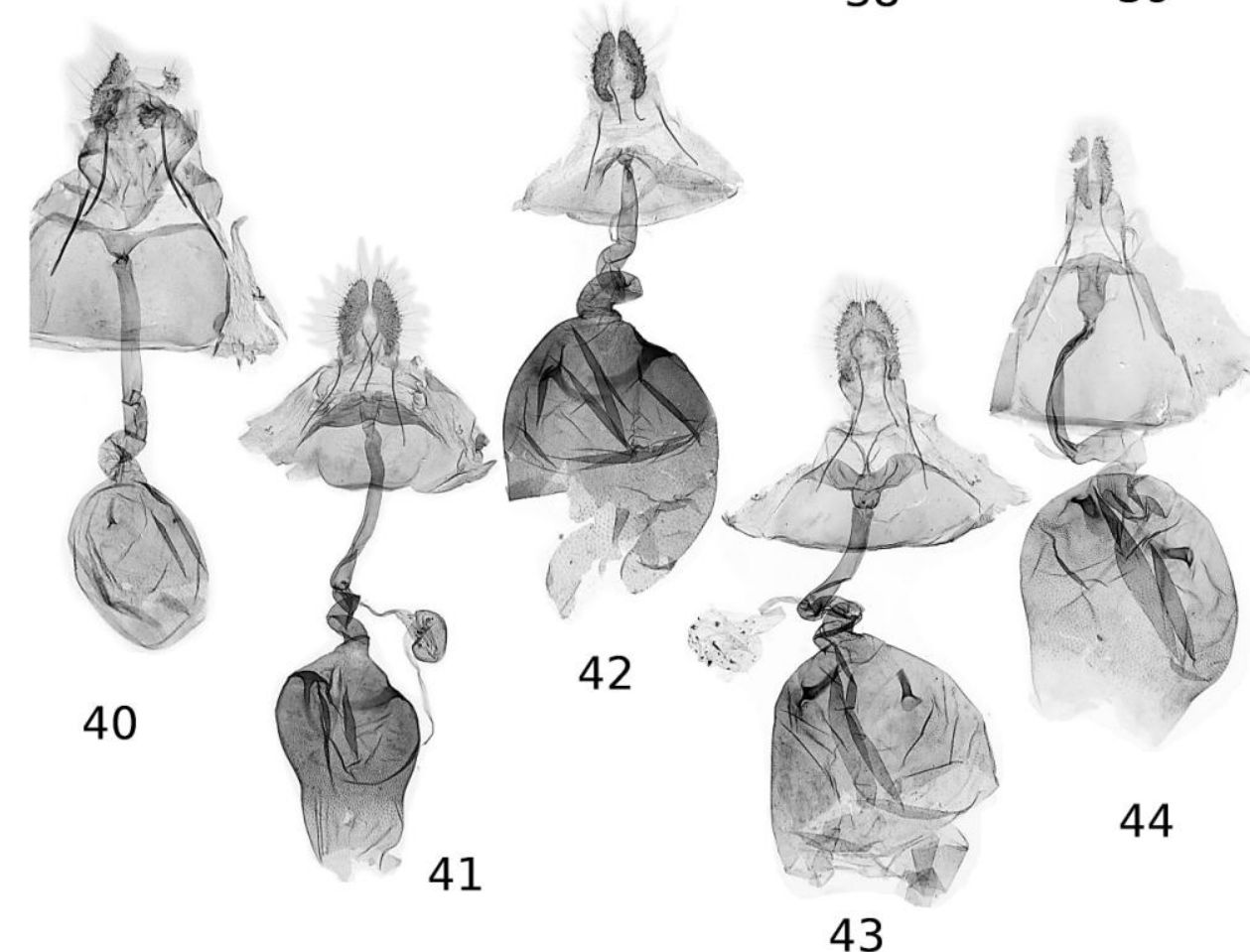

Figs 36-44. Female genitalia: 36 - Iatitaia intercalata sp. n., paratype, 37 - Miojuqa albivertex sp. n., paratype, $38-M$. albovirens sp. n., paratype, $39-M$. splendida sp. n., paratype, $40-M$. viridicans sp. n., paratype, 41 - Latortona tortolana sp. n., paratype, $42-$ L. vulga sp. n., paratype, $43-$ L. cosmelia sp. n., paratype, $44-$ L. diplocosmea sp. n., paratype. 

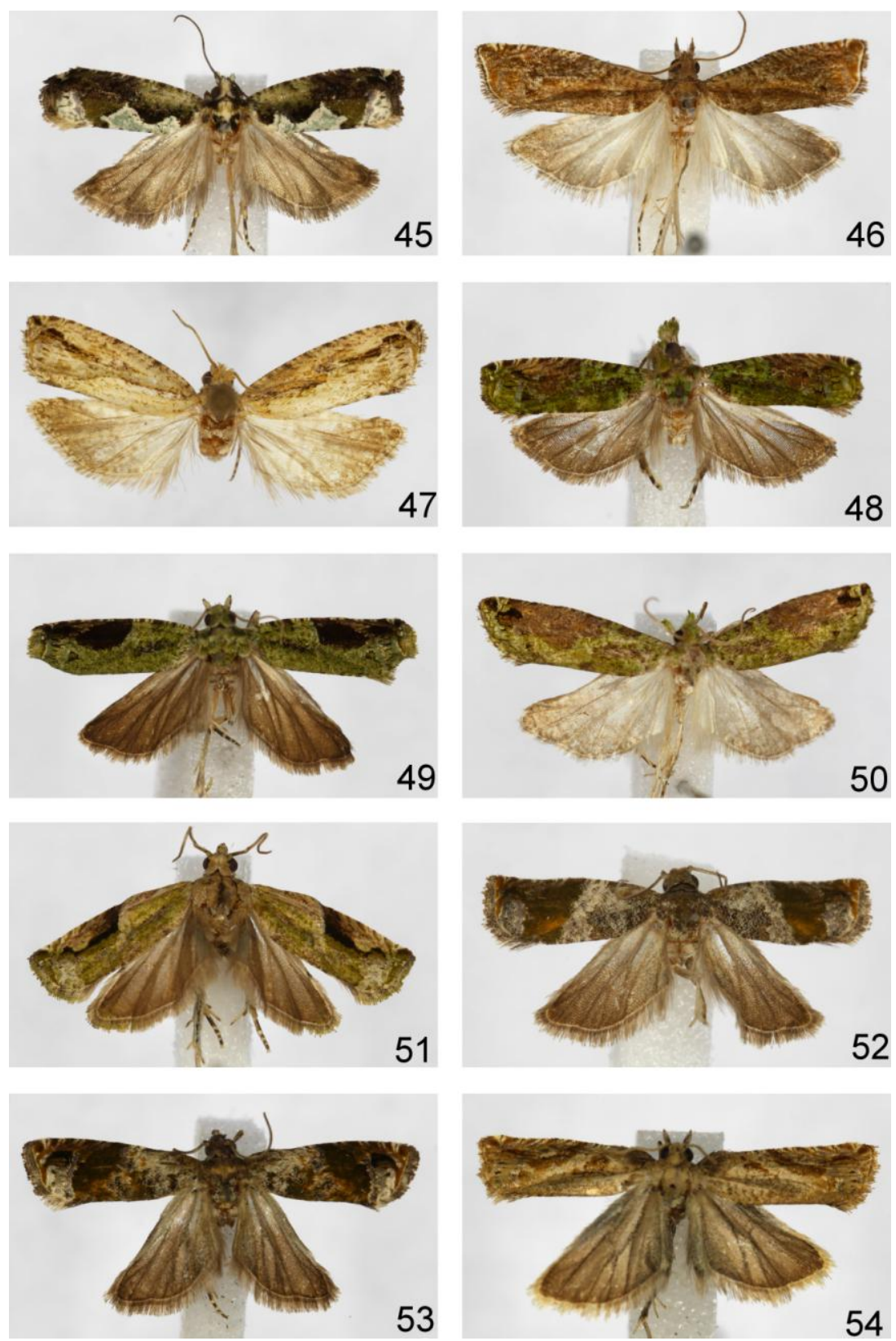

Figs 45-54. Adults: 45 - Quebradnotia paulista sp. n., holotype, 46 - Laculataria brunnescens sp. n., holotype, 47 - L. cactsocia sp. n., holotype, 48 - L. elliptica sp. n., holotype, 49 - L. atrovirens sp. n., holotype, 50 - L. cajasana sp. n., holotype, 51 - Crocidosema monias sp. n., holotype, $52-$ C. obliquata sp. n., holotype, 53 - Crocidosema sp., GS 1035 WZ, $54-$ C. platea sp. n., holotype. 

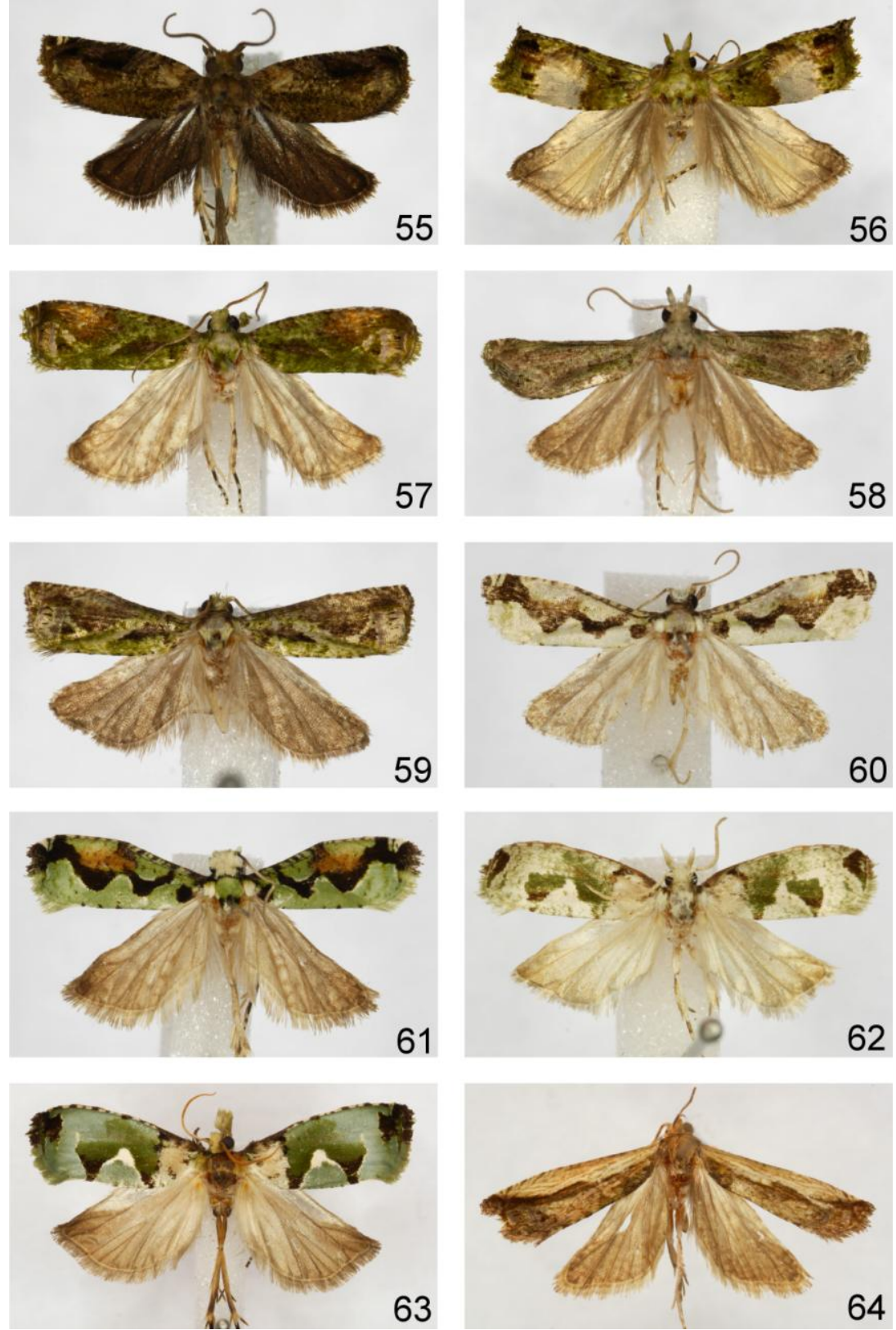

Figs 55-64. Adults: 55 - Crocidosema mangaritibae sp. n., holotype, 56 - Domaldona latiptera sp. n., holotype, 57 - Iatitaia itatiaiae sp. n., holotype, 58 - I. pithana sp. n., holotype, 59 - I. intercalata sp. n., holotype, 60 - Miojuqa visibilis sp. n., holotype, $61-M$. albivertex sp. n., holotype, $62-M$. albovirens sp. n., holotype, $63-M$. splendida sp. n., holotype, $64-M$. defecta sp. n., holotype. 

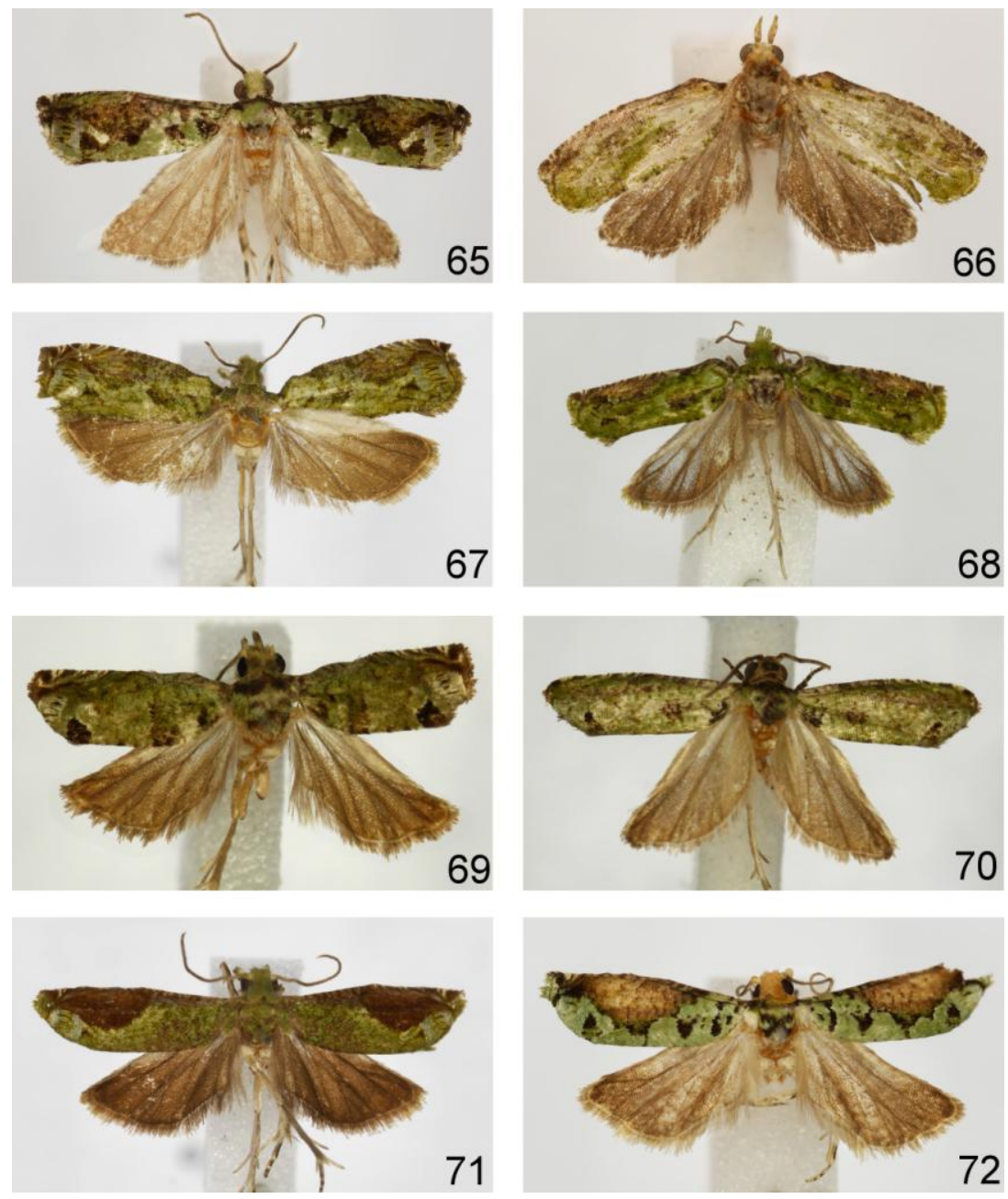

Figs 65-73. Adults: 65 - Miojuqa viridicans sp. n., holotype, 66 - Latortona tortolana sp. n., holotype, 67 - L. rhamna sp. n., holotype, 68 - L. viridirufa sp. n., holotype, 69 - Laculataria tornota sp. n., holotype, 70 - Latortona vulga sp. n., holotype, $71-L$. mimosa sp. n., holotype, $72-$ L. cosmelia sp. n., holotype, $73-$ L. diplocosmea sp. n., holotype.

\section{Remarks}

RAZOWSKI \& WOJTUSIAK (2006) included eight specimens from Cordillera de Mérida, Venezuela under nolckeniana, and illustrated adults (Fig. 35) and their male (Figs 94, 95) and female (Fig. 114) genitalia. We propose for those specimens a new name based on the name of the country of its origin. 


\section{Quebradnotia paulista sp. n.}

(Figs 29, 45)

\section{Diagnosis}

$Q$. paulista is related and externally similar to $Q$. nolckeniana and $Q$. venezolana. $Q$. paulista has a brownish hindwing, which in the latter two species is whitish proximally; a short sclerite of the antrum; and a partly membranous proximal part of the ductus bursae (an illdefined cingulum). In facies, $Q$. paulista is similar to the Ecuadoran $Q$. saragurae RAZOWSKI \& WoJTUSIAK, 2008 (known from the female only) but differs from it in having a nonvariegate whitish costobasal area of the forewing and a brownish hindwing.

\section{Description}

Wingspan $15 \mathrm{~mm}$. Head and thorax whitish; basal part of tegula and median marking blackish. Ground colour whitish in costobasal and tornal area, pale greenish dorsally where white edged; costal strigulae indistinct, except for posterior one; speculum separated from dorsal part of ground colour area. Remaining parts of wing with black marks and suffusions. Cilia brown-grey, whiter at tornus. Hindwing pale brownish; cilia similar.

Male unknown.

Female genitalia (Fig. 29). Ovipositor as in Q. nolckeniana; sterigma ill-defined (a membranous area); sclerite of antrum moderately short, tapering proximally; median and anterior part of ductus bursae with indistinct, irregular sclerotization; signa large.

\section{Material}

Holotype female: "Brasil: S[ao]P[aulo], São Paulo 1000 m, 29. I. 1993, V.O. BECKER Col., Col. BECKER 86843”; GS 1098 WZ.

\section{Etymology}

The specific name refers to the type-locality; paulista is the Brazilian expression for a citizen of São Paulo.

\section{Laculataria brunnescens sp. $\mathrm{n}$.}

(Figs 1, 46)

\section{Diagnosis}

Laculataria brunnescens is most similar to L. chondrites RAZOWSKI \& WOJTUSIAK, 2006 from Venezuela, but L. brunnescens has a more oblique forewing termen, more yellow-brown colouration, strongly setose socii, and an oval cucullus. 
RAZOWSKI J. and BECKER V.O.: Systematics and Faunistics of Neotropical Eucosmini 317

\section{Description}

Wingspan $17 \mathrm{~mm}$. Head pale cinnamon brown, thorax darker. Forewing weakly expanding posteriorly; costa slightly bent with slender fold to middle; termen moderately oblique, weakly sinuate. Ground colour whitish, strongly suffused with cinnamon brown, best preserved as a trace of the submedian interfascia, subtornally, and in form of costal strigulae. Markings darker than suffusions preserved as costal half of median fascia connected obliquely with apex, and weak tornal spot. Cilia brownish. Hindwing glossy cream, brownish on peripheries; cilia creamish.

Male genitalia (Fig. 1). Uncus slender, strongly sclerotized; socius large, bristled; neck of valva slender; sacculus broadly angulate; cucullus broad, oval, with ventral marginal spines; aedeagus small.

Female unknown.

\section{Material}

Holotype male: "Mexico: Ver[acruz], Las Minas, 2200 m, 5. VI. 1997, V.O. BECKER Col.; Col. V.O. BECKER 109566”; GS 1359 WZ.

\section{Etymology}

The name refers to the colouration of the forewing; Latin: brunnescens - becoming brown.

\section{Laculataria cactsocia sp. $\mathbf{n}$.}

(Figs 2, 47)

\section{Diagnosis}

L. cactsocia is related to L. brunnescens and L. asymmetra RAZOWSKI \& WOJTUSIAK, 2006 from Venezuela, but differs from the latter in having a short uncus and long cucullus, and from L. asymmetra chiefly by the short neck of the valva and the elongate cucullus.

\section{Description}

Wingspan $17.5 \mathrm{~mm}$. Head and thorax brownish cream. Forewing indistinctly broadening medially; costa weakly convex; termen slightly oblique. Ground colour cream weakly tinged, suffused and sprinkled brown. Costal strigulae and speculum more or less concolorous; divisions brown. Markings dark brown in form of vertical lines at wing base and middle; similarly coloured remnant of subterminal fascia and spot at wing apex. Cilia brownish. Hindwing brownish cream with weak darker strigulation, brownish on peripheries; cilia cream. 
Male genitalia (Fig. 2). Uncus strong, distinctly bifurcate; socius large, setose; sacculus angulate; ventral incision of valva short; cucullus elongate, broad proximally; aedeagus moderately large.

Female unknown.

\section{Material}

Holotype male: "Curitiba, Paraná, Brasil 920 m, 28. XII. 1974, V.O. BECKER col.; Col. BECKER No 10739”; GS 858 WZ.

\section{Etymology}

The name refers to the spiny socii; Latinized Greek: cact - a spiny plant [cactus] and socius.

\section{Laculataria elliptica sp. n.}

(Figs 3, 48)

\section{Diagnosis}

In male genitalia, L. elliptica is similar to L. splendida RAZOWSKI \& WOJTUSIAK, 2009 from Ecuador, but L. elliptica has a broad, caudally rounded cucullus and oval socii. In facies, L. elliptica differs from L. splendida by its green forewing colouration.

\section{Description}

Wingspan $13.5 \mathrm{~mm}$; head, terminal part of labial palpus, and thorax greenish. Forewing not expanding terminad; costa mostly straight with slender fold; termen convex postmedially. Ground colour greenish, refractively edged at marking edges, except for costal area of posterior half of wing which is brownish; costal strigulae creamish; divisions brown; speculum brownish green. Markings green with a few darker, diffuse marks. Cilia brownish cream with green parts. Hindwing brownish white, brownish in posterior half, with brownish venation; cilia pale brownish.

Male genitalia (Fig. 3). Uncus long, slender, with terminal thorn; socius broad, oval with submedian fold and long hairs; neck of valva long with ventral convexity medially; sacculus weakly angulate; cucullus short, convex caudally; aedeagus approximately as long as uncus, slender; cornuti numerous, long.

Female unknown. 
RAZOWSKI J. and BECKER V.O.: Systematics and Faunistics of Neotropical Eucosmini 319

\section{Material}

Holotype male: "Cuba: S[an]t[ia]go $1500 \mathrm{~m}$, Sier.[ra] Maestra, P.[inar] Cuba; V.O. BECKER Col, Col. BECKER 73606”; GS 1267 WZ.

\section{Etymology}

The specific epithet concerns the shape of the socius; modern Latin: elliptica - elliptic.

\section{Laculataria nigroapicata RAZOWSKI \& WOJTUSIAK, 2006}

\section{Material}

Ten specimens from Ecuador: Indanza, Morona Province, 2800 m, 24. XII. 1992, BC 103499 and Loja, Loja Province, 21. XII. 1992, BC 103166.

\section{Remarks}

L. nigroapicata was described from two males collected in the Province of MoronaSantiago at an altitude of $2950 \mathrm{~m}$. It is characterized by a rather slender, greenish forewing. It is most probably conspecific with L.tubuligera RAZOWSKI \& WOJTUSIAK, 2008 - syn. n. from the Province of Zamora Chinchipe from $2480 \mathrm{~m}$, which has a brownish colouration of the forewing. Our specimens are somewhat intermediate between the examples from the typelocalities of the two species and show slight variation in the shapes of wings and colouration.

\section{Laculataria atrovirens sp. $\mathbf{n}$.}

(Figs 30, 49)

\section{Diagnosis}

L. atrovirens is related to L. nigroapicata RAZOWSKI \& WOJTUSIAK, 2006 but differs from it chiefly in having very broad bases of the socii and a long neck of the valva.

\section{Diagnosis}

Wingspan $16 \mathrm{~mm}$. Head and thorax pale greenish with darker scaling. Forewing weakly expanding terminad, termen slightly oblique. Ground colour whitish with greenish suffusions, densely strigulated and spotted green; costal strigulae whitish; divisions blackish; speculum white-green. Markings black in form of an oval costal half of median fascia and a smaller blotch at wing apex separated by brownish costal suffusion. Cilia brownish with green parts. Hindwing brown, cilia paler.

Male unknown. 
Female genitalia (Fig. 30). Ovipositor short; papillae anales broad, broadly fused medially; eighth tergite very short; apophyses short, apophyses posteriores with lobate bases; posterior part of sterigma indistinct, anterior part with proximally convex lateral lobes; antrum sclerite short, connected with medioposterior sclerite (cingulum?) by means of a short membrane; signa large, unequal in size. Subgenital sternite with broad submedian lobes finely connected with anterior sclerite; proximal sclerite consisting of weak median rib armoured by large sclerotic lateral lobes.

\section{Material}

Holotype female: "Brasil: M[a]T[o Grosso], Chapada do Guimaraes 800 m, 26. X. 1993, V.O. BECKER Col; Col. BECKER 893346”; GS 1044 WZ.

\section{Etymology}

The name refers to the colouration of forewings: Latin: ater - black and virens - green.

\section{Laculataria cajasana sp. $\mathbf{n}$.}

(Figs 4, 50)

\section{Diagnosis}

L. cajasana is related to L. nigroapicata RAZOWSKI \& WOJTUSIAK, 2006 but has a distinct neck of the valva, broad bases of the socii and a deep pocket of the socius filled with hairs.

\section{Description}

Wingspan $17 \mathrm{~mm}$. Head and thorax pale brownish suffused and marked with green, labial palpus greenish posteriorly. Forewing hardly broadening terminad; costa straight to middle (to end of fold); termen straight, moderately oblique. Ground colour greenish marbled and dotted darker green, brownish triangle from mid-costa to before apex of wing; costal strigulae whitegreen, subapical one whitish; divisions brownish, spot at apex blackish; speculum indistinct; a few white dots in tornal area. Markings brownish green consisting of dorsobasal and median blotch and black spot before apex; some black dots subtornally. Cilia worn. Hindwing brownish cream, browner in posterior half where brown strigulation present; cilia whitish.

Male genitalia (Fig. 4). Tegumen expanding posteriorly; uncus long, slender; socius large, broad basally with large submedian pocket filled with thin scent scales; basal part of valva short, broad; neck long; sacculus weakly angulate; ventral lobe of cucullus broad, dorsal lobe triangular; aedeagus small.

Female unknown. 
RAZOWSKI J. and BECKER V.O.: Systematics and Faunistics of Neotropical Eucosmini 321

\section{Material}

Holotype male: "Ecuador: Azuay, Cajas 3150 m, 21. XII. 1992, V.O. BECKER Col; Col. BECKER 103284”; GS 1028 WZ.

Etymology The name refers to the type locality, Cajas.

\section{Crocidosema ZELLER, 1847}

Based chiefly on genital characters, we transfer the following species from Epinotia to Crocidosema. See also the list of genera. For the original papers, see the references.

Crocidosema albocephalaeis (RAZOWSKI \& WOJTUSIAK, 2010), comb. n.;

Crocidosema brunneomacula (RAZOWSKI \& WOJTUSIAK, 2009), comb. n.;

Crocidosema chloana (RAZOWSKI \& WOJTUSIAK, 2006b), comb. n.;

Crocidosema illepidosa (RAZOWSKI \& WOJTUSIAK, 2006b), comb. n.;

Crocidosema lineana (RAZOWSKI \& WOJTUSIAK, 2008a), comb. n.;

Crocidosema longistria (RAZOWSKI \& WOJTUSIAK, 2008c), comb. n.;

Crocidosema marcapatae (RAZOWSKI \& WOJTUSIAK, 2010), comb. n.;

Crocidosema microscyphos (RAZOWSKI \& LANDRY, 2008), comb. n.;

Crocidosema panda (RAZOWSKI \& WOJTUSIAK, 2008b), comb. n.;

Crocidosema rotundata (RAZOWSKI \& WOJTUSIAK, 2009), comb. n.

\section{Crocidosema monias sp. $\mathbf{n}$.}

(Figs 5, 31, 51)

\section{Diagnosis}

Crocidosema monias is related to the Cuban C. cingularia RAZOwSKI \& BECKER, 2014 from which it differs by its smaller size, the narrower forewing, and the darker colouration; in the female genitalia the new species is distinct chiefly by a large postostial sterigma, the sclerite of the antrum, the signa, and the presence of an ill-defined scent organ on the subgenital sternite.

\section{Description}

Wing span $18 \mathrm{~mm}$. Head and thorax cream brown. Forewing slightly expanding terminally; fold to mid-costa; termen slightly concave beneath apex, weakly oblique. Ground colour pale cream brown in dorsal half of wing, indistinctly tinged greenish; white subterminally, greenish 
grey along termen; costal strigulae cream; divisions brownish; speculum ill-defined. Markings in form of dark brown costal half of median fascia dorsally fused with longitudinal marking extending from end of median cell. Cilia greenish grey. Hindwing brownish, cilia similar.

Variation. Female similar to male but with creamish costoproximal half of forewing, longitudinal black fascia originating at mid-base of wing, and dorsal half of wing suffused brownish grey.

Male genitalia (Fig. 5). Uncus atrophied; socius short, broad, convex laterally with short inner process and posterior group of setae; sacculus weakly angulate; neck of valva broad, short with group of hairs at middle of posterior edge of basal cavity; cucullus elongate with small ventral lobe; aedeagus moderately slender; cornuti long.

Female genitalia (Fig. 31). Apophyses fairly long; antrum sclerite as long as postostial sterigma; cingulum long; signa strong, broad basally. Subgenital sternite with weak semicircular rib (remnant of scent organ).

\section{Material}

Holotype male: "Cuba: S[an]tiago. Turguino 470 m, 27/29. VII. 1990, V.O. BECKER Col; Col. BECKER 73392"; GS 1338 WZ. Paratypes male and female, identical labels (GS 1337 WZ, $1339 \mathrm{WZ}$ ). Two specimens mentioned in the remarks are not included in the type series: male (Pinar Rio, Sierra Rosario 400 m, 4-6. X. 1989, BC 70688, GS 1241 WZ) and female (Guantanamo, Imias, Farola, 15. VII. 1990, BC 72663, GS 1259 WZ).

\section{Etymology}

The specific epithet refers to the systematic position of the species; Greek: monias - living lonely.

\section{Remarks}

This species is included in Crocidosema based on the female genitalia; the male genitalia differ from the majority of the congeners chiefly by the shape of the valva and socii; the uncus is strongly reduced as in E. sinuncus RAZOWSKI \& BECKER, 2014.

Specimens from Guantanamo and Pinar Rio are small (11 and $12 \mathrm{~mm}$ ), pale coloured, with forewing ground colour greyish, traces of brownish grey markings and a black stripe from the end of the median cell to the wing apex. The genitalia are almost identical with the types. 
RAZOWSKI J. and BECKER V.O.: Systematics and Faunistics of Neotropical Eucosmini 323

\section{Crocidosema obliquata sp. n.}

(Figs 6, 52)

\section{Diagnosis}

Crocidosema obliquata is related to the Colombian Crocidosema dolicha (RAZOWSKI \& WOJTUSIAK, 2011), comb. n. (see remarks below) but obliquata is distinguished chiefly by its rounded ventral lobe of the cucullus and its broad uncus.

\section{Description}

Wingspan $13 \mathrm{~mm}$. Head and thorax dark greyish brown, tegula scaled whitish posteriorly. Forewing uniformly broad throughout; costa weakly convex to before middle, termen concave medially. Ground colour white sprinkled and sparsely strigulated black to median fascia; basal blotch rudimentary; apical area pale rust; posterior half of wing suffused grey; speculum grey and white; costal strigulae minute, whitish; divisions blackish brown fused with postmedian costal suffusion. Median fascia black-brown marked rust submedially; subterminal fascia paler. Cilia blackish, in apical part pale rust. Hindwing brown-grey paler basally; cilia concolorous with middle of wing.

Male genitalia (Fig. 6). Uncus broad, slightly expanding terminally; socius broad, convex posteriorly; valva fairly broad with broad neck and shallow ventral incision; angle of sacculus weak; cucullus elongate with rounded ventral lobe and subdorsal triangular prominence; aedeagus moderately broad, cornuti long.

Female unknown.

\section{Material}

Holotype male: "Brasil: M[inas]G[erais 1400 m, Serra do Cipó, 17-19. IV. 1991; V.O. BECKER Col; Col. BECKER 78166”; GS 1126 WZ. Paratype an identically labelled male.

\section{Etymology}

The specific name refers to the shape of the proximal edge of the forewing median fascia; from Latin: obliquus - oblique.

\section{Remarks}

In the genitalia, this and following four species strongly differ from the type species of the genus and probably deserve a different genus. However, the external and genital differences are not enough. The caudal prominence of the cucullus can be found in a few other New World species (e.g., Epinotia huroniensis BROWN, 1980, Crocidosema argentonivea RAZOWSKI $\&$ BECKER, 2014). We are placing the newly described species in Crocidosema following the placement of the last-mentioned species. 
We transfer Pseudexentera dolicha RAZOWSKI \& WOJTUSIAK, 2011, comb. n. to Crocidosema based on the male genitalia and venation.

\section{Crocidosema sp.}

(Figs 7, 32, 53)

\section{Remarks}

Three specimens from Ecuador (Tungurahua, Rio Verde 1600 m, 26. XII. 1992, BC 104074; GS $1035 \mathrm{WZ}$ ) are certainly closely related to $C$. obliquata and similar in facies and male genitalia (see figures). The female from Carchi (Maldonado 2200 m, 9-11. I. 1993; BC 105514) may represent another closely related species but externally differs from the former in having a dorsopostmedian blotch of the forewing.

\section{Crocidosema platea sp. $\mathbf{n}$.}

(Figs 8, 33, 54)

\section{Diagnosis}

C. platea is related to $C$. dolicha and the two previously described species, but $C$. platea has a yellowish-brown colouration of the forewings, a broad uncus and a ventral part of the cucullus.

\section{Description}

Wingspan $15 \mathrm{~mm}$. Head and thorax brownish cream, subterminal part of labial palpus greyish brown. Forewing not expanding terminad; costa straight from beyond base where short fold present; apex rounded; termen weakly concave medially. Ground colour brownish cream sprinkled and delicately strigulated brownish; costal strigulae long, whitish; divisions brownish; speculum yellowish. Markings yellow-brown, preserved in costal half of wing and a darker fascia on vein R5. Cilia brown cream. Hindwing grey-brown; cilia paler.

Variation. Female similar to male but with slightly yellower

hue of the forewing and better developed strigulation in basal area; hindwing brownish.

Male genitalia (Fig. 8). Uncus short, broad; socius elongate; henion well developed; neck of valva slender, short; incision deep; angle of sacculus distinct; ventral part of cucullus broad, caudal edge sinuate beneath short, subdorsal prominence; aedeagus long, slender, extending dorso-terminally. 
Female genitalia (Fig. 33). Ovipositor moderately long; apophyses long, slender; sterigma convex distally followed by a weak plate; sclerite of antrum long, tapering proximad; cingulum long; signa large. Subgenital sternite with slender ventral sclerite perpendicularly extending posteriorly.

\section{Material}

Holotype male: "Brasil: S[anta]C[atarina], São Joaquim 1400 m, 25. X. 1995, V.O. BECKER Col; Col. BECKER 98167”; GS 1048 WZ. Paratypes 2 males labelled as above and 2 females with similar labels but dated 2. II. 1993, BC 87787, one with GS $1050 \mathrm{WZ}$.

\section{Etymology}

The specific name refers to the shape of the uncus; Greek: platys - flat.

\section{Crocidosema mangaritibae sp. $\mathbf{n}$.}

(Figs 9, 55)

\section{Diagnosis}

Crocidosema mangaritibae is closely related to $C$. platea but is quite different in facies, having a brown forewing ground colour and a large dark brown costal blotch. The male genitalia of $C$. mangaritibae are characterized chiefly by a slenderer uncus and a longer aedeagus.

\section{Description}

Wingspan $10 \mathrm{~mm}$. Head and thorax greyish brown. Forewing not expanding terminally; costa weakly convex with short fold; termen slightly concave medially. Ground colour whitish, strigulated greyish brown submedially, strongly suffused grey-brown in dorsal and terminal areas of wing, tinged yellowish brown at costa postbasally; costal strigulae small, whitish, invisible along costal blotch, divisions brown; speculum brownish grey. Cilia brownish. Hindwing brown, cilia similar.

Male genitalia (Fig. 9). Uncus moderately broad, short; socius elongate; neck of valva short, fairly broad; proximal edge of ventral incision short; aedeagus long, slender.

Female unknown.

\section{Material}

Holotype male: "Brasil: R[io de]J[aneiro], Mangaritiba 150 m, 20. I. 1993, V.O. BECKER Col; Col. BECKER 85726"; GS 1042 WZ. 


\section{Etymology}

The name refers to the type locality, Mangaritiba.

\section{Domaldona gen. $\mathbf{n}$.}

Type-species: Domaldona latiptera sp. n.

\section{Diagnosis}

Domaldona belongs to the Epinotia-group of genera but is distinct from other genera (e.g. Crocidosema, Epinotia) by its large terminal lobes of the tegumen, mediolateral setose socii and the presence of the dorsal forewing scent organ. The posterior hairy lobe of the basal cavity of valva is dorsal, large and resembles that of Argepinotia RAZOWSKI \& PELZ, 2007.

\section{Description}

Venation as in Epinotia. Forewing scent organ parallel to the edge of costal fold present extending along Sc vein, consisting of long area of dense capitate cream scales.

Male genitalia. Tegumen slender with large terminal lobes; uncus slender situated in middle of terminal part of tegumen between the lobes; pedunculi long; socii median setose posteriorly; valva slender with moderately long neck and broad dorsal hairy lobe of posterior edge of the basal cavity; sacculus angle weak; cucullus slender with rounded ventral lobe and small, setose dorsal lobe, and sharp dorsal process of the caudal edge; aedeagus slender, cornuti long; posterior part of anellus broad.

Female unknown.

\section{Biology and distribution}

Nothing is known of the biology except for dates of collection of the moths: January. They occur at an altitude of $2200 \mathrm{~m}$ in the Province of Carchi, Ecuador.

\section{Etymology}

The generic name is an anagram of the type locality name of the type-species, Maldonado in Ecuador. 


\section{Domaldona latiptera sp. $\mathbf{n}$.}

(Figs 10, 56)

\section{Diagnosis}

In facies, Domaldona latiptera, the only representative of the genus, resembles Crocidosema marumbiana RAZOWSKI \& BECKER, 2014 from Paraná, Brazil, but D. latiptera has a broad, greenish forewing. In the male genitalia latiptera resembles the Colombian $C$. dolicha RAZOWSKI \& WOJTUSIAK, 2011 but has distinct tegumen lobes and a long subdorsal process from the caudal edge of the cucullus.

\section{Description}

Wingspan $20 \mathrm{~mm}$. Head and thorax brownish cream, vertex and median part of thorax tinged olive green, terminal part of labial palpus brown. Forewing slightly expanding terminad; costa almost straight; costal fold to mid-costa; apex pointed; termen moderately oblique, sinuate. Dorsal wing scent organ as described for the genus. Ground colour pale greenish strigulated brown, greyish in dorsopostmedian area limited by brownish tornal blotch marked by dark submedian spot, extending towards costa as a brownish fascia, latter connected to apical area by means of concolorous costal suffusion; costal strigulae cream; divisions brown; speculum ill-defined whitish grey. Cilia pale grey-brown. Hindwing cream grey; cilia similar.

Male genitalia (Fig. 10) as described for the genus.

Female unknown.

\section{Material}

Holotype male: "Ecuador: Carchi, Maldonado 2200 m, 9-11. I. 1993, V.O. BECKER Col; Col. BECKER 105311"; GS 823 WZ. Paratype an identically labelled, not dissected male.

\section{Etymology}

The specific name refers to the shape of the forewing; Latin: latus - broad and Greek: pteron - wing.

\section{Iatitaia gen. $\mathbf{n}$.}

Type species: Iatitaia itatiaiae sp. n.

\section{Diagnosis}

Iatitaia is related to and externally similar to Chimoptesis POWELL, 1964, but Iatitaia has a minute, bifurcate uncus; slender, serrate, well sclerotized lateral socii; an emarginate caudal 
edge of the cucullus; a large posterior sclerite of the sterigma; and undifferentiated lateral edge of the subgenital sternite.

\section{Description}

Markings as in species of Chimoptesis POWELL and Epinotia HüBNER. Venation as in Epinotia.

Male genitalia. Distal part of tegumen broad, well sclerotized; uncus minute, bifid with very short basal part; socius strong, heavily sclerotized, serrate posteriorly; valva broad basally with distinct neck and ventral incision; sacculus angulate; cucullus broad, with rounded caudal edge forming ventroposterior, naked lobe; aedeagus simple surrounded by large anellus, connected with bases of socii by means of short sclerite; cornuti long, slender.

Female genitalia. Ovipositor, eighth tergite, and apophyses short; posterior part of sterigma broad, sclerotized; antrum sclerite distinct, variably long; cingulum long with proximal origin of ductus seminalis; small sclerite at base of ductus bursae; blades of signa long, variably broad. Subgenital sternite with broad lobes weakly emarginate posteriorly; no scent organ.

\section{Biology and distribution}

Nothing is known of the biology except for the dates of collection of the adult (January, April, October) and altitudes $1400-2100 \mathrm{~m}$. All three species are known from Brazil (states of Bahia and Rio de Janeiro).

\section{Etymology}

The generic name is an anagram of the name of the type locality of one species, Itatiaia.

Iatitaia itatiaiae $\mathbf{s p .} \mathbf{n}$.

(Figs 11, 34, 57)

\section{Diagnosis}

In facies, I. itatiaiae resembles Chimoptesis obliquaria RAZOWSKI \& BECKER, 2015, and in male genitalia it resembles I. pithana sp. n., but itatiaiae has a greenish forewing and a distinctly angulate sacculus.

\section{Description}

Wingspan $17 \mathrm{~mm}$. Head and medio-proximal part of thorax creamish (in female greenish), tegula and remaining surface green. Forewing costa weakly convex, termen slightly concave beneath apex. Ground colour whitish with variable greenish suffusion; costal strigulae fine, whitish; divisions green; speculum brownish cream; large brownish blotch at costa 
postmedially. Markings indistinct brownish green; costobasal area dotted green. Cilia green. Hindwing creamish mixed pale brown, in posterior half strigulate brown; cilia whitish.

Female similar to male.

Male genitalia (Fig. 11). Uncus processes slender; socius uniformly bent; small lobe at angle of sacculus; ventral incision of valva deep; cucullus expanding posteriorly with distinct ventral lobe; aedeagus simple, almost as long as straight part of sacculus. Otherwise as described for the genus.

Female genitalia (Fig. 34). Posterior sclerite of sterigma elongate-oval, weakly convex in middle posteriorly; cingulum long; small sclerite at base of ductus bursae present; signa slender. Median part of subgenital sternite framed by slender sclerite.

\section{Material}

Holotype: "Brasil: R[io de]J[aneiro], Itatiaia 2100 m, 25. I. 1993, V.O. BECKER Col; Col. Becker 86485"; GS 1054 WZ and 1053 WZ, respectively. paratypes 2 males, same data as holotype, not dissected.

\section{Iatitaia pithana sp. $\mathbf{n}$.}

(Figs 12, 35, 58)

\section{Diagnosis}

In facies, I. pithana is similar to the Venezuelan Laculataria chlorochara RAZOWSKI \& WOJTUSIAK, 2006a but has grey forewings; in male genitalia it is similar to I. itatiaiae sp. $\mathrm{n}$. but differs from it in having a shallow ventral incision of the valva.

\section{Description}

Wing span $14 \mathrm{~mm}$. Head whitish, labial palpus and thorax greenish grey. Forewing expanding terminad; costa straight with long, slender fold; termen slightly sinuate, not oblique. Ground colour pale greenish grey, tinged brownish in posterior third of wing, dotted greenish, with a few whitish minute markings; costal strigulae fine, whitish, divisions greenish, small except for blackish green subapical one. Cilia concolorous with wing. Hindwing brownish; cilia paler.

Variation. Female somewhat darker than male with black spots in a row from end of median cell to apex. Other markings weak; grey-black traces of basal blotch at dorsum.

Male genitalia (Fig. 12). Processes of uncus fairly short; socius strongly curved, serrate terminally; basal part of valva and neck short; angle of sacculus rounded; cucullus elongate, expanding posterad, distinctly convex terminally; aedeagus longer than sacculus, curved proximally; anellus broad at aedeagus. 
Female genitalia (Fig. 35). Postostial part of sterigma large forming broad lateral wings; antrum large, expanding terminally; cingulum long; signa broad.

\section{Etymology}

The specific name refers to the distinguishing characters of the genitalia; Greek: pithanos convincing.

\section{Material}

Holotype male: "Brasil: BA[hia], Morro do Chapeu 1400 m, 23-24. IV. 1991, V.O. BECKER Col; Col. BECKER 78353”; GS 1134 WZ; paratype female, identical label, GS 1135 WZ.

\section{Iatitaia intercalata sp. $\mathbf{n}$.}

(Figs 13, 36, 59)

\section{Diagnosis}

In facies, I. intercalata is somewhat similar to Laculataria nigroapicata RAZOWSKI \& WOJTUSIAK, 2006 from Ecuador, but I. intercalata has brownish hindwing; from I. pithana this species differs chiefly in the slender posterior half of the socius.

\section{Description}

Wingspan $13 \mathrm{~mm}$. Head and posterior part of thorax whitish, proximal part of thorax brownish. Forewing expanding terminad; costa straight with fold to middle; termen concave beneath apex. Ground colour white in major part, suffused green, finely strigulated black; costal strigulae fine, whitish; divisions brown; speculum white, tinged green posteriorly. Markings black in form of spots on green basal blotch, triangular median blotch white edged dorsally and posteriorly, and paler subapical suffusions. Cilia greenish grey to mid-termen, white otherwise. Hindwing brownish, cilia similar.

Variation. Female wingspan $15 \mathrm{~mm}$; head whitish, thorax greenish with black marks; areas of white ground colour larger, an additional area at costa postmedially. Hindwing pale brownish cream with brownish strigulation.

Male genitalia (Fig. 13). Base of uncus short; base of socius broad, posterior half slender, terminal part serrate; proximal third of valva short; neck slender; sacculus rounded; cucullus subrounded; aedeagus moderately long.

Female genitalia (Fig. 36). Posterior plate of sterigma convex; antrum sclerite broad, short; cingulum long; blades of signa slender. 
RAZOWSKI J. and BECKER V.O.: Systematics and Faunistics of Neotropical Eucosmini 331

\section{Material}

Holotype male: "Brasil: S[anta]C[atarina], Bom Jardim da Serra 1500 m, 1-4. X. 1996, V.O. BECKER Col; Col. BECKER 108512"; GS 1058 WZ; paratypes 3 males, 2 females (one with GS $1057 \mathrm{WZ}$ ), identical labels.

\section{Etymology}

The name refers to the position of the species within the genus; Latin: intercalata - added.

\section{Miojuqa gen. n.}

Type-species: Miojuqa visibilis sp. $\mathrm{n}$.

\section{Diagnosis}

Based chiefly on the lateral position of the socii, Miojuqa is similar to and probably most closely related to Chimoptesis. It differs from the latter in the presence of a slender, well sclerotized uncus, a strongly sclerotized, hooked socius and a short cucullus.

\section{Description}

Venation as in Epinotia.

Male genitalia. Pedunculi long, posterior part of tegumen broad; uncus slender; socius hooked, usually well sclerotized; basal part of valva broad, neck slender; cucullus short; anellus around aedeagus strongly enlarged; aedeagus moderately large, simple; cornuti long, numerous; henion well developed consisting of two sclerites.

Female genitalia. Eighth tergite short; postostial sterigma with submedian sclerites and concavities or membranous; cup-shaped part developed; cingulum variable; signa large. Subgenital sternite simple or with posterior emarginations.

\section{Biology and distribution}

Moths collected in October at the altitude of 1400 and $1500 \mathrm{~m}$. Three Brazilian, one Ecuadoran, and one Colombian species known.

\section{Etymology}

The name is an anagram of the second part of the name of the type locality, São Joaquim. 


\section{Miojuqa visibilis sp. $\mathbf{n}$.}

(Figs 14, 60)

\section{Diagnosis}

In facies, $M$. visibilis resembles some species similar to Quebradnotia nolckeniana; in the male genitalia it is most similar to M. albivertex $\mathrm{sp} . \mathrm{n}$.

\section{Description}

Wingspan $15 \mathrm{~mm}$. Head and thorax white, collar and base of tegula brown and black, respectively. Forewing expanding terminad; costa straight, fold to middle, slender; termen weakly oblique, indistinctly concave medially. Ground colour white; costal divisions blackbrown; speculum atrophied. Markings black-brown consisting of dorsobasal blotch and Mshaped longitudinal fascia fused with broad, apical blotch. Cilia blackish interrupted whitish in apical part of wing, white in dorsal half. Hindwing brownish cream pale towards base; cilia similar.

Male genitalia (Fig. 14) as described for genus; neck of valva long, cucullus short with large ventral lobe.

Female unknown.

\section{Material}

Holotype male: "Brasil: S[anta]C[atarina], São Joaquim, 25. X. 1995, V.O. BECKER Col; Col. BECKER 98170”; GS 1107 WZ.

\section{Etymology}

The specific epithet refers to the distinct colouration of the forewing; Latin: visibilis visible.

\section{Miojuqa albivertex sp. $\mathbf{n}$.}

(Figs 15, 37, 61)

\section{Diagnosis}

In facies Miojuqa albivertex is similar to Quebradnotia nolckeniana (ZELLER) and some related species. From $M$. albivertex this species differs in having a green median part of the thorax and forewing, a shorter neck of the valva, and a slender posterior margin of the subgenital sternite. 
RAZOWSKI J. and BECKER V.O.: Systematics and Faunistics of Neotropical Eucosmini 333

\section{Description}

Wingspan $17 \mathrm{~mm}$. Dorsal part of head and terminal third of labial palpus, collar and base of tegula black; median part of thorax green with two posterior black spots. Forewing as in $M$. albivertex but with broader concavity of termen. Ground colour green, paler in dorsal part of wing; costal strigulae white; divisions and dots along dorsum black; speculum ill-defined. Markings black consisting of two basal spots and fascia from mid-base to apex convex twice broadening dorsally; apex blotch with two distinct white costal strigulae, pale rust costal suffusion at black fascia, postmedially. Cilia green in costal third black. Hindwing brownish with paler cilia.

Variation. Female similar to male but with differently convex, partly white edged median longitudinal fascia and atrophied pale ferruginous costal blotch of forewing.

Male genitalia (Fig. 15). Uncus slender, tapering terminad; socius broad basally, hooked terminally; broad basal part of valva large, tapering posteriorly; neck short, slender; angle of sacculus weak; cucullus short with well-developed lobes and rounded caudal edge; aedeagus moderate; cornuti long; henion well sclerotized.

Female genitalia (Fig. 37). Eighth tergite short; basal plate of posterior apophyses well developed; antrum sclerite expanding posterad; posterior part of sterigma convex; cingulum long; basal sclerite of ductus bursae weak; signa large.

\section{Material}

Holotype male: "Brasil: S[anta]C[aterina], Bom Jardin da Serra 1500 m,1-4. X. 1996, V.O. BECKER Col; Col. BECKER 108513”; GS 1093 WZ. Paratype identically labelled female, GS $1092 \mathrm{WZ}$.

\section{Miojuqa albovirens sp. n.}

(Figs 16, 38, 62)

\section{Diagnosis}

In facies, M. albovirens resembles Quebradnotia saragurae RAZOWSKI \& WOJTUSIAK, 2008 from Ecuador, but the latter has a black costal forewing marking. From the two preceding species M. albovirens differs chiefly in having a club-shaped uncus. Female genitalia differ from those of M. splendida chiefly in having a broad cup-shaped part of sterigma and large postostial sclerites.

\section{Description}

Wingspan $17 \mathrm{~mm}$. Head and thorax white, base of tegula black. Forewing broad; costa weakly convex; termen almost straight, slightly oblique. Ground colour white with weak, 
sparse greenish strigulation; costal divisions greenish; speculum absent. Markings: costal remnant of basal blotch and subapical blotch black; diffuse fascia extending from postbasal part of dorsum to mid-costa green; dorsal blotch representing median fascia green, marked with black. Cilia black at apex, green to mid-termen, otherwise white. Hindwing cream, tinged brownish posteriorly; cilia cream.

Variation. Female wingspan $18 \mathrm{~mm}$. Similar to male but more intensely green; green markings with black elements and white edges; dorsal area of ground colour triangular, white.

Male genitalia (Fig. 16). Pedunculus broad, short; uncus broadly rounded apically; socius tapering terminad with apical thorn; sacculus broad, rounded, with row of short spines beyond angle, tapering towards slender part of neck; cucullus short; triangular ventral lobe armoured by a spine; aedeagus broad; cornuti numerous.

Female genitalia (Fig. 38). Sclerites of postostial sterigma weak forming shallow posterior concavities, better developed proximally; cup-shaped part short; sclerite of ductus bursae broad; signa moderate.

\section{Material}

Holotype male: "Brasil: S[anta]C[aterina], São Joaquim 1400 m, V.O. BECKER Col; Col. BECKER 98172”; GS 1096 WZ. Paratype identically labelled female, GS 1095 WZ.

\section{Etymology}

The specific name refers to the colouration of the forewing; Latin: albus - white, virens green (from vireo, I am green).

\section{Miojuqa beryllina (MEYRICK, 1927), comb. n.}

MEYRICK (1924) described Eucosma beryllina from Mt. Tolima, Colombia; RAZOWSKI \& WoJTUSIAK (2010) recorded it from Department of Pasco, Peru and erroneously placed it in Gretchena HEINRICH, 1923.

\section{Miojuqa splendida sp. $\mathbf{n}$.}

(Figs 17, 39, 63)

\section{Diagnosis}

M. splendida is closely related to the Colombian M. beryllina, but M. splendida has a longer socius, a triangular lobe from the caudal edge of the cucullus, it lacks the ventral spine 
of the latter and there is a different dorsal part of the forewing median fascia. Female genitalia are similar to those of M. albovirens but with a short cup-shaped part of sterigma.

\section{Description}

Wingspan $26 \mathrm{~mm}$. Head cream, labial palpus olive green, cream basally; thorax olive cream with weak, blackish postmedian transverse line. Forewing expanding posteriorly; costa straight, fold reduced, dense group of rather short scent scales basally; ground colour bluish green, in part glossy, base of wing cream black edged and sparsely scaled, white dorsoposteriorly; large, triangular bluish white edged blotch at mid-dorsum between reversely directed dark green blotches, posterior finely white edged; black, partly white edged markings at apex of wing; costal strigulae whitish; divisions black; speculum absent. Cilia pale green, black in apical third. Hindwing pale brown, cream brown basally; cilia brownish.

Variation. Female similar to male but forewing tinged white cream costally and apical marking broader.

Male genitalia (Fig. 17). Uncus broad, short, concave apically; socius slender with terminal thorn; valva broad to middle with slender posterior part of neck; sacculus angulate marked by row of dense small spines from angle to ventral lobe of cucullus; dorsal lobe of latter broad; hairless subventral lobe of caudal edge present; aedeagus fairly broad; cornuti long.

Female genitalia (Fig. 39). Ovipositor short; apophyses thin; sterigma in major part membranous with posterior folds and two lateral pockets; antrum sclerite large; cingulum broad, anterior; signa large.

\section{Material}

Holotype male: "Ecuador: Carchi, Maldonado 2200 m, 9-11. I. 1993, V.O. BECKER Col; Col. BECKER 105305"; GS 817. Paratypes an identically labelled pair, female with GS 818 WZ.

\section{Etymology}

The name refers to the beautiful colouration of the moth; Latin: splendidus - splendid.

\section{Miojuqa defecta sp. n.}

(Figs 18, 64)

\section{Diagnosis}

In male genitalia, Miojuqa defecta is similar to M. splendida sp. n. but differs from it chiefly by the lack of an uncus and the short row of valval spines. In facies, $M$. defecta differs 
from M. splendida in having a slenderer and cream coloured (in M. splendida - greenish) forewing. It is not similar to other species of the Epinotia-group.

\section{Description}

Wingspan $18 \mathrm{~mm}$. Head creamish, labial palpus, vertex and thorax brownish. Forewing weakly expanding terminad; costa bent at middle, fold slender, reaching mid-costa; termen weakly oblique, almost straight. Ground colour in costal part of wing cream, suffused brownish costally; costal strigulae indistinct, cream; divisions brownish, speculum distinct, pale edged; dorsal triangle of ground colour cream brown followed by grey suffusion; dorsobasal and postbasal area brownish; brown fascia from wing base to apex, black brown costally. Cilia greyish brown. Hindwing pale brown, cilia creamer.

Male genitalia (Fig. 18). Top of tegumen slightly convex; socius broad to middle, well sclerotized laterally; neck of valva long, slender medially; sacculus rounded posteriorly; cucullus short, subtriangular, armoured with a short row of spines extending from top of ventral lobe; aedeagus slender, straight.

Female unknown.

\section{Material}

Holotype male: "Brasil: Banhado, P[a]R[aná], Quatro Barras 850 m, 27. II. 1970, BECKER \& LAROCA; Col. BECKER 10864"; GS 862 WZ.

\section{Etymology}

The name refers to an absence of the uncus; Latin: defecta - defected.

\section{Miojuqa viridicans sp. $\mathbf{n}$.}

(Figs 19, 40, 65)

\section{Diagnosis}

In colouration, M. viridicans somewhat resembles the Ecuadoran Epinotia chloana RAZOWSKI \& WOJTUSIAK, 2006b, but $M$. viridicans has a large white triangular blotch at the dorsum.

\section{Description}

Wingspan $13 \mathrm{~mm}$. Head and thorax greenish; labial palpus with black and brown marks; collar, base of tegula and posterior marks of thorax black. Forewing expanding terminad; costa almost straight with slender fold to middle; termen almost straight not oblique to middle. Ground colour greenish; costal strigulae fine, white; divisions blackish; spots of speculum 
present, lines reduced. Markings black: basal blotch consisting of several spots; median triangle separated from remnant of tornal blotch by means of white stripe limited at costa by pale rust suffusion. Costal half of cilia black, remaining whitish, black scaled. Hindwing pale brownish, cilia similar.

Variation. Female forewing ground colour greener than in male; black markings larger, more complete; rust subcostal suffusion absent.

Male genitalia (Fig. 19). Uncus moderately large, slightly expanding basally and terminally; socius very large with serrate posterior part and minute dorsal spinulation; angle of sacculus broadly rounded; neck of valva fairly long; cucullus convexly rounded caudally; aedeagus short.

Female genitalia (Fig. 40). Antrum sclerite expanding posteriorly, sterigma membranous; cingulum long; basal sclerite of ductus bursae small; one signum small, the other vestigial.

\section{Material}

Holotype male: "Brasil: M[inas]G[erais], Serra de Cipó 1400 m, 17-19. IV. 1991, V.O. BECKER col; Col. BECKER 78168”; GS 1055 WZ; female paratype with identical label, GS $1056 \mathrm{WZ}$.

\section{Etymology}

The name refers to the colouration of the moth; Latin: viridicans - greenish.

\section{Latortona gen. $\mathbf{n}$.}

Type-species: Latortona tortolana sp. n.

\section{Diagnosis}

Latortona is similar to Chimoptesis but has a well sclerotized, broad posterior part of the tegumen from which the sclerotized socii extend; the uncus is absent while in Chimoptesis the uncus is short, broad, helmet-shaped. Posterior part of the subgenital sternite of Latortona is in major part membranous without the lateral margins extending from the ventral edge of the antrum sclerite.

\section{Description}

Venation as in Epinotia.

Male genitalia. Socii spiny or serrate terminally; basal part of valva broad; neck weakly differentiated; cucullus spinose, with indistinct ventral lobe; aedeagus simple; henion absent. 
Female genitalia. Sterigma membranous; sclerite of antrum well developed; cingulum long; signa large. Subgenital sternite without scent organ or folds, membranous posteriorly.

\section{Biology and distribution}

The genus is Neotropical, distributed from the West Indies (Puerto Rico, British Virgin Islands, Cuba) to Brazil. Nothing is known of the biology except for the collecting dates (I, V VIII) and altitudes $(180-1100 \mathrm{~m})$.

\section{Etymology}

The generic name is an anagram of one of the specific names, tortolana.

\section{Latortona tortolana sp. $\mathrm{n}$.}

(Figs 20, 41, 66)

\section{Diagnosis}

In facies, L. tortolana somewhat resembles the Venezuelan Laculataria chondrites RAZOWSKI \& WOJTUSIAK, 2006, but tortolana has a greenish forewing ground colour.

\section{Description}

Wingspan $14 \mathrm{~mm}$. Head cream, vertex scaled brown; thorax brownish green. Forewing not expanding terminad; costa slightly convex with fold to $1 / 3$; termen concave beneath apex, then convex. Ground colour green; costal strigulae whitish; divisions and apex brown; speculum absent. Markings brownish, rudimentary, in form of costal half of median fascia. Cilia rubbed. Hindwing brown, cilia damaged (remnants brownish).

Variation. Female wingspan $16 \mathrm{~mm}$. Similar to male; ground colour of forewing slightly paler with a few darker strigulae; costal strigulae larger, divisions blackish; cream diffuse blotch above costal remnant of median fascia; blackish shade subapically. Remnants of cilia cream.

Male genitalia (Fig. 20). Top of tegumen slightly concave; socius almost uniformly broad, bent, with spined terminal part; basal part of valva broad; costa convex postbasally; neck straight with row of setae in terminal third; angle weak; cucullus elongate without ventral lobe, with strong spines; aedeagus slender.

Female genitalia (Fig. 41). Sterigma indistinct; sclerite of antrum short; cingulum long; signa large. Subgenital sternite without scent organ, with large posterior membrane. 
RAZOWSKI J. and BECKER V.O.: Systematics and Faunistics of Neotropical Eucosmini 339

\section{Material}

Holotype male: "British Virgin Is.: Tortola I: Mt. Sage National Park 460 m, 13-15. VII. 1987, V.O. BECKER \& S.E. MILLER Col; Col. BECKER 66921”; GS 1261 WZ. Paratypes: 2 males and two females with identical labels, one female with GS $1262 \mathrm{WZ}$.

\section{Etymology}

The species is named after its collection place, Tortola Island.

\section{Latortona rhamna sp. $\mathbf{n}$.}

(Figs 21, 67)

\section{Diagnosis}

In facies, L. rhamna resembles the Colombian "Paedisca" pristinana Zeller, 1877, but $L$. rhamna has a pale green forewing and a convex termen.

\section{Description}

Wingspan $16 \mathrm{~mm}$. Head greenish grey, labial palpus grey; thorax greenish. Forewing slightly expanding terminad, broadest at middle; costa weakly convex, fold to $1 / 3$; termen broadly concave beneath apex, then convex. Ground colour green with series of blackish transverse lines in basal half of wing; indistinct brownish suffusion at distal part of costal arm of median cell; costal strigulae green to mid-costa, otherwise white; divisions brown; speculum developed. Markings black in form of incomplete basal and tornal blotches. Cilia pale brown in part tinged green. Hindwing brown, cilia paler.

Male genitalia (Fig. 21). Terminal part of tegumen slightly convex; socius lateral with strong terminal hook; costa of valva convex postbasally; neck indistinct, narrowing posteriorly; sacculus with posterior group of long setae and weak angle; cucullus short, slender, without ventral lobe, with strong marginal spines; aedeagus slender, bent basally.

Female unknown.

\section{Material}

Holotype male: "Brasil: D[istrito]F[ederal], Planaltina 1100 m, 5. VI. 1989, V.O. BECKER Col; Col. BECKER 96682"; GS 1125 WZ.

\section{Etymology}

The specific name refers to the spinulation of the cucullus; Greek: rhamnos - thorny. 


\section{Latortona viridirufa sp. $\mathrm{n}$.}

(Figs 22, 68)

\section{Diagnosis}

In facies, L. viridirufa resembles the Colombian "Paedisca" pristinana ZELLER, 1877, but $L$. viridirufa has a green forewing with black marks. In the shape of the cucullus $L$. viridirufa is similar to the two preceding species.

\section{Description}

Wingspan $12 \mathrm{~mm}$. Head and thorax green. Forewing not expanding terminally; costa straight except for base which is strongly convex, fold short; termen convex. Ground colour green, costal blotch pale brownish; costal strigulae white; divisions blackish; speculum indistinct. Markings black consisting of groups of spots at wing base, postbasally and medially, tornal blotch incomplete; subapical suffusion present. Cilia green, black at apex. Hindwing whitish, partly transparent, brownish on peripheries and venation; cilia brownish.

Male genitalia (Fig. 22). Tegumen rounded terminally; socius slender with median projection and terminal thorns; basal part of valva broad with costa convex; sacculus weakly angulate with group of setae in posterior third; neck of valva short; cucullus slender, strongly spiny, one marginal spine (left valva) long.

Female unknown.

\section{Material}

Holotype male: "Puerto Rico: Patillas 590 m, Viii. 1987, V.O. BECKER Col; Col. BECKER 68277"; GS 1212 WZ.

\section{Etymology}

The name refers to the colouration of the forewing; Latin: viridis - green, rufa - red (rusty).

\section{Latortona tornota sp. $\mathrm{n}$.}

(Figs 23, 69)

\section{Diagnosis}

In facies, L. tornota somewhat resembles the Ecuadoran Epinotia pusula RAZOWSKI \& BECKER, 2014, but the forewing ground colour in L. tornota has a greenish hue. 
RAZOWSKI J. and BECKER V.O.: Systematics and Faunistics of Neotropical Eucosmini 341

\section{Description}

Wingspan $11 \mathrm{~mm}$. Head creamish; thorax whitish green, collar and base of tegula black. Forewing uniformly broad; costa almost straight, fold fairly long; termen convex. Ground colour whitish green, whiter in dorsal half, with darker strigulation; costal strigulae fine, white; division greenish; speculum developed. Markings: blackish spot at wing base subdorsally; postbasal fascia rudimentary, greenish spotted black; median fascia indistinct; tornal blotch black. Cilia rubbed, remnants brownish. Hindwing brownish, cilia paler.

Male genitalia (Fig. 23). Apex of tegumen broad; socius upcurved, setose posteriorly; basal part of valva without costal extrusion; neck short; sacculus angulate, setose posteriorly; cucullus elongate-oval; aedeagus fairly short; cornuti numerous, long.

Female unknown.

\section{Material}

Holotype male: "Brasil: RO[ndonia], 1800 m Porto Velho, 24.IV - 12.V.1989, V.O. BECKER Col; Col. BECKER 76350”; GS 1127 WZ.

\section{Etymology}

The specific name refers to the forewing marking; Latin: tornus and nota - a sign.

\section{Latortona vulga p. $\mathbf{n}$.}

(Figs 24, 42, 70)

\section{Diagnosis}

In facies, L. tornota somewhat resembles the Ecuadoran Epinotia pusula RAzOWSKI \& BECKER, 2014, but vulga has a pale greenish forewing ground colour. It is related and similar to I. tornota but differs from it chiefly in having a narrower top of the tegumen, the lack of the sacculus angle, and a slender cucullus.

\section{Description}

Wingspan $11 \mathrm{~mm}$. Head and collar brown, thorax greenish. Forewing as in tornota; ground colour white-green, dotted green; costal strigulation delicate. Markings indistinct except for dorsobasal and subtornal spots which are black. Cilia damaged. Hindwing pale brown, cilia paler.

Male genitalia (Fig. 24). Apical edge of tegumen short, convex; socius up-curved, narrowing terminad, setose posteriorly; basal part of valva slender; neck fairly broad; sacculus not angulate, setose posteriorly; cucullus moderately slender; aedeagus fairly short. 
Female genitalia (Fig. 42). Sterigma membranous; sclerite of antrum short; cingulum shorter than anterior part of ductus bursae; signa large. Subgenital sternite folded posteriorly.

\section{Material}

Holotype male: "Cuba: Holguin, Pin.[ar] Mayari 640 m, VII. 1990, V.O. BECKER Col; Col. BECKER 72035”; GS 1271. Paratype an identically labelled female; GS 1272 WZ.

\section{Etymology}

The specific name refers to the shape of socius, Latin: vulga - wry.

\section{Latortona mimosa sp. $\mathbf{n}$.}

(Figs 25, 71)

\section{Diagnosis}

In facies, $L$. mimosa resembles $L$. vulga and to some degree E. pusula RAZOWSKI $\&$ BECKER, 2014 but $L$. mimosa has a distinct rust brown costal blotch of the forewing.

\section{Description}

Wing span $15 \mathrm{~mm}$. Head and thorax brown-green. Forewing not expanding terminad; costa straight, fold to middle; termen convex. Ground colour yellowish green with darker part and silver white dots along middle of wing strongly agglomerated along rust brown costal blotch; costal strigulae and speculum indistinct. Cilia brownish. Hindwing dark brown; cilia similar.

Male genitalia (Fig. 25). Top of tegumen convex; socius moderately long; basal part of valva short with convex basal part of costa; neck long, slender; sacculus angulate; cucullus elongate-oval, heavily spined caudally; aedeagus slender.

Female unknown.

\section{Material}

Holotype male: "Brasil: S[ão]P[aulo], São Paulo 1000 m, 29. I. 1993, V.O. BECKER Col; Col. BECKER 36340”; GS 1049 WZ.

\section{Etymology}

The specific name refers to structure of the genitalia; Spanish Latinized; mimosa - delicate. 
RAZOWSKI J. and BECKER V.O.: Systematics and Faunistics of Neotropical Eucosmini 343

\section{Latortona cosmelia sp. $\mathbf{n}$.}

(Figs 26, 43, 72)

\section{Diagnosis}

In facies, L. cosmelia resembles Laculataria chlorochara RAZOWSKI \& WOJTUSIAK, 2006 from Venezuela, but L. cosmelia has a pale brownish costal forewing blotch similar to that in Miojuqa albivertex sp. $\mathrm{n}$.

\section{Description}

Wingspan $15 \mathrm{~mm}$. Head brownish cream; thorax green with black marks, posterior half of tegula white. Forewing slightly expanding posteriorly; costa almost straight, fold to middle; termen straight beneath apex. Ground colour vivid green, large postmedian triangular blotch at costa pale brownish with browner strigulae; costal strigulae brown cream, two subapical ones and a strip beneath apex white; divisions black. Markings black consisting of several spots and edge of costal triangle. Cilia grey to mid-termen otherwise white. Hindwing brownish; cilia paler.

Variation. Female similar to male with browner dorsal suffusion of costal triangle.

Male genitalia (Fig. 26). Top of tegumen almost straight; socius broad, subtriangular posteriorly; neck of valva tapering towards cucullus; sacculus angulate; cucullus short, broad, rounded caudally.

Female genitalia (Fig. 43). Postostial sterigma broad with submedian ribs; sclerite of antrum rounded proximally; cingulum long; signa large. Subgenital sternite concave in middle posteriorly with large membranous posterior fold, without scent organ.

\section{Material}

Holotype male: "Brasil: S[anta]C[atarina], São Joaquim 1400 m, 25. X. 1995, V.O. BECKER Col; Col. BECKER 93169"; GS 1059 WZ; Paratypes two males and two females with identical labels, one female with GS 1060.

\section{Etymology}

The name refers to the presence of the forewing costal blotch; from Greek: kosmeo - I am decorating. 


\section{Latortona diplocosmea sp. $\mathbf{n}$.}

(Figs 27, 44, 73)

\section{Diagnosis}

In facies, L. diplocosmea resembles the Ecuadoran Epinotia brunneomacula RAZOWSKI \& WojTUSIAK, 2009, but L. diplocosmea has greenish white median part of dorsum.

\section{Description}

Wingspan $16 \mathrm{~mm}$. Head and thorax cinnamon brown. Posterior part of forewing not expanding terminad; costa straight, fold to beyond middle; termen slightly concave towards middle. Ground colour brownish, paler postmedially, whitish green in middle dorsally and in ocellar area; costal strigulae brownish, indistinct, divisions browner; spots of speculum minute, blackish. Markings dark brown represented by dorsopostbasal mark followed by paler, diffuse fascia directed toward median cell, and dark brown tornal blotch. Cilia concolorous with postmedian part of ground colour. Hindwing brownish, paler basally; cilia pale brown.

Variation. Female similar to male but with brown strigulated basal half of forewing and darker markings.

Male genitalia (Fig. 27). Top of tegmen broad; socius tapering terminad; basal part of valva broad, neck fairly long, slender; sacculus angulate; cucullus short, convex caudally with reduced ventral lobe and large, triangular dorsal lobe; aedeagus moderately long, slender.

Female genitalia (Fig. 44). Apophyses long, slender; postostial sterigma convex medially; antrum broad; cingulum long; posterior membranous part of ductus bursae much shorter than its proximal part; signa large.

\section{Material}

Holotype male: "Brasil: S[anta]C[aterina], Bom Jardim do Serra 1500 m, 1-4. X. 1996, V.O. BECKER Col; Col. BECKER 108514"; GS 1043 WZ. Paratype one male labelled as above and female from Monte Castello 1300 m, Santa Catarina, 11. I. 1993, BC 87129, GS 1041 WZ.

\section{Etymology}

The name refers to the colouration of the forewings; Greek: diplosis - double and cosmea adornment.

\section{REFERENCES}

BRown R. L. 1986. Resurrection of Catastega CLEMENS and revision of the Epinotia vertumnana (ZELLER) species-group (Tortricidae: Olethreutinae). Journal of the Lepidopterological Society 40(4): 327-346. 
RAZOWSKI J. and BECKER V.O.: Systematics and Faunistics of Neotropical Eucosmini 345

BRown J.W. 2005. World Catalogue of Insects. Vol. 5: Tortricidae (Lepidoptera). Apollo Books, Stenstrup.

HANNEMANn H. J. 1961. Kleinschmetterlinge oder Microlepidoptera, I. Die Wickler (s. str.) (Tortricidae) [in] F. DAHL (ed.). Die Tierwelt Deutschlands, 3. Gustav Fischer, Jena, 852-941.

HORAK M. 2006. Monographs on Australian Lepidoptera. Volume 10. Olethreutine moths of Australia (Lepidoptera: Tortricidae). CSIRO Publishing. Canberra.

RAZowsKi J. 1987. Monographs of Polish fauna, 15. Butterflies (Lepidoptera) of Poland. Part VII, additions and Eucosmini. Państwowe Wydawnictwo Naukowe, Warszawa. (in Polish)

RAZOwSKI J. 1989. The genera of Tortricidae (Lepidoptera). Part II: Palaearctic Olethreutinae. Acta zoologica cracoviensia 32(7): 107-328.

RAZOWSKI J. 2003. Tortricidae (Lepidoptera) of Europe. Volume 2. Olethreutinae. F. Slamka, Bratislava.

RAZOWSKI J., BECKER V.O. 2014. Systematics and faunistics of Neotropical Eucosmini, 2: Epinotia HÜBner, Catastega Clemens, and Crocidosema Zeller (Lepidoptera: Tortricidae). Polish Journal of Entomology 83(1): 23-59.

RAZOWSKI J., BECKER V. O. 2015. Systematics and faunistics of Neotropical Eucosmini. 1. Chimoptesis POWELL, 1064 (Lepidoptera: Tortricidae). Zootaxa 3941(2): 204-220.

RAzowski J., LANDRY B., RoQue-Albedo L. 2008. The Tortricidae (Lepidoptera) of the Galapagos Islands, Ecuador. Revue suisse de Zoologie 115(1): 185-220.

Razowski J., Pelz V. 2007. One new genus and four new species of Tortricidae (Lepidoptera) from Argentina. Polish Journal of Entomology 76(1): 11-19.

RAZOWski J., WoJTUSiaK J. 2006a. Tortricidae from Venezuela (Lepidoptera: Tortricidae). SHILAP Revista de Lepidopterologia 34(133): 35-79.

Razowski J., Wojtusiak J. 2006b. Tortricidae (Lepidoptera) from the Valley of Rio Gualaceo, East Cordillera in Ecuador, with descriptions of new taxa. Acta zoologica cracoviensia 49B(1-2): 17-53.

RAzOWSKi J., WoJTUSiaK J. 2008a. Tortricidae (Lepidoptera) from the mountains of Ecuador. Part 1: Southern Highlands. Acta zoologica cracoviensia 51B(1-2): 7-41.

RAzOWSKi J., WoJTUSiaK J. 2008b. Tortricidae (Lepidoptera) from the mountains of Ecuador. Part III: Western Cordillera. Genus 19(3): 497-575.

RAZOWSKi J., WoJTUSiak J. 2008c. Tortricidae (Lepidoptera) from the mountains of Ecuador. Part IV: Eastern Cordillera. Acta zoologica cracoviensia 51B(1-2): 119-187.

RAZOWSKi J., WoJTUSiaK J. 2010. Tortricidae (Lepidoptera) from Peru. Acta zoologica cracoviensia 51B(1-2): 73-159.

SwATSCHEK B. 1958. Abhandlungen der Larvalsystematik der Insekten, Bd. 3. Die Larvalsystematik der Wickler (Tortricidae und Carposinidae). Akademieverlag, Berlin.

Received: 23 May 2017

Accepted: 13 September 2017 